\title{
MAKING SPACE AND NATION MEANINGFUL THROUGH BORDERS AND THEIR REPRESENTATIONS IN ROMANIAN GEOGRAPHY TEXTBOOKS, DURING THE FIRST HALF OF THE 20 TH CENTURY
}

\author{
Oana-Ramona ILOVAN \\ Babeș-Bolyai University, Faculty of Geography, Department of Regional Geography and Territorial Planning, and Territorial \\ Identities and Development Research Centre, 5-7 Clinicilor Street, 400006, Cluj-Napoca, Romania, oana.ilovan@ubbcluj.ro; \\ Humboldt-Universität zu Berlin, Geography Department, Unter den Linden 6, 10099, Berlin, Germany, \\ oana-ramona.ilovan@hu-berlin.de
}

DOI: http://doi.org/10.23740/TID220205

\section{ABSTRACT}

Lately, in Romania and abroad, research about the hidden agendas of educational discourses circulated by school textbooks has become richer. This research focuses on the process of bordering that took place in 1918 and the creation of Greater Romania and on the new borders and their representations in Geography school textbooks before and after that year. These representations are considered in the form of both text and images. First, I describe these representations and, secondly, I uncover and explain their intentions in the respective historical and geographical contexts. As History and Geography have been always viewed among the most influential subject matters in school, I employed visual methodology and discourse analysis to study Geography of Romania school textbooks - officially accepted products. The research material is made of Geography school textbooks. From a temporal perspective, my research material includes textbooks that were circulated starting with 1902 and in the 1930s. In addition, I assessed the degree to which Geography education was politicised. Results showed that, in the first half of the $20^{\text {th }}$ century, the wished-for or newly-established and contested borders of Romania generated a lengthy and argumentative discourse about state borders and about the history and geography of the territories inhabited by Romanians. Ethnocultural identity concepts and conceptions of national identity were provided for the young and not only. Geography of Romania school textbooks were not apolitical, but reinforced a socio-spatial consciousness, based on the natural and anthropic features of the borders and on how they were represented, revealing the social practice of the educational discourse about border areas.

Keywords: territorial identities, lower secondary grades education, history and official discourse, visual analysis, discourse analysis

Cite this article as: Ilovan, O.-R. (2020). Making Space and Nation Meaningful through Borders and Their Representations in Romanian Geography Textbooks, during the First Half of the 20 ${ }^{\text {th }}$ Century. Territorial Identity and Development, 5(2), 79-116. DOI: http://doi.org/10.23740/TID220205

\section{INTRODUCTION}

Borders are the result of historically-contingent processes and, in Europe, the first half of the $20^{\text {th }}$ century was well-known for multiple changes of nation-state borders because of the two World Wars. In this article, I focus on the educational discourse on state borders in two Geography textbooks: before and after Romania joined the Great War (it participated as a belligerent in the war starting with 1916). 
Socialisation with space is promoted through education. I started from the premises that for the Romanian territory and social-cultural background, the most important conceptual anchor is the mythology of the homeland (i.e. "patria", the Romanian nation; cf. Verdery, 1991) and therefore I explored how symbols were discursively connected to the concept of borders and their landscape (natural and cultural) in Geography of Romania school textbooks, during the first half of the $20^{\text {th }}$ century. The changes or fixity of Romanian state borders were seen through the lens of the nation and of distinctive Romanian features. I considered the hypothesis that some topics were overrepresented at the expense of others, supporting thus the stereotyping process of the Romanian space. One of these themes was that of Romania's borders; the topic of borders was an overrepresented one:

\begin{abstract}
"At its most elemental, the geographic perspective involves making sense of presence and absence, in the same way that historians engage remembering and forgetting. [...] Cognitive understanding of place and region involves recognizing those present and past qualities of place that give character as well as those absent elements that similarly constitute difference" (Entrikin, 2018, p. 46).
\end{abstract}

\title{
RESEARCH AIM, QUESTIONS AND OBJECTIVES
}

In this article, drawing on the revival of border studies in the last decades (Agnew, 2008; Paasi, 1996; Wilson \& Donnan, 2012), I see maps as peculiar historical texts, not only geographical and cartographical products: "Border' has been a key category for social scientists since the 19th century when modern state-building and nation-building processes began to intensify in Europe" (Paasi, 2012, p. 2303). Borders have been defined "as historically contingent institutions that are constituted in and constitutive of the perpetual production and reproduction of territories" (Paasi, 2012, p. 2304).

When establishing the aim of my research, I considered the necessity of not taking for granted spatial representations and territorial identities but investigate the way they are produced and reproduced ( $c f$. Botea, 2013). In such a scientific context, my research is focused on representations of Romania's state borders.

This article aims to analyse representations of borders in Romanian Geographyschool textbooks published and circulated at the beginning of the $20^{\text {th }}$ century, when Romania joined World War I and Greater Romania was created, and during the 1930s. Thus, it is relevant for the respective decades to analyse school textbooks "in terms of identity construction" (Silova, Yaqub \& Palandjian, 2014, p. 109), considering their educational intentions. I considered the following research questions: What were the socio-spatial constructs that circulated in the geographical educational narrative about Romania's borders? How did school textbooks (i.e. Geography of Romania ones) make borders central to students' (and later adults') consciousness? How did the authors of these textbooks attach meaning to the space of borders, transforming it into place? What places were transformed into iconic representations through geographical education when considering the nation's borders? Of what consisted the overarching pedagogy of space within these Geography school textbooks concerning borders and bordering processes?

To answer these main research questions, other secondary ones had to be dealt with: Which were the intentions of the included images as they were declared by their authors? How were students and people in general supposed to experience the visual texts? So, which were the promoted values and beliefs in the visual imagery that the school system employs in the act of educating students and all Romanians? These questions receive answers in the textbooks 
themselves, where authorsstate and explain their pedagogical aims. Therefore, the keyresearch question is how were people's structures of feelings and expectations constructed through images/visual discourse about the borders?

Based on these research questions, I identified the following research objectives: (1) to describe representations of borders and nation - to identify common recurring topics, syntagms, symbols, in the visual and written text accompanying the former, the so called "emblematic or recurring discourse" (Silova, Yaqub \& Palandjian, 2014, p. 111) on the Romanian state borders, (2) to identify the identity features of the Romanian state borders, (3) to analyse the discourse of visual imagery circulated, during the creation of Greater Romania, in Geography of Romania school textbooks, with focus on visual and textual representations of borders and of the Romanian nation, (4) to uncover and explain their intentions (as representations can have also an agency of their own) contingent to the highly politicised historical and geographical context.

A secondary aim of this article is to go beyond the above-mentioned objectives and support further research, which could explore the continuity of educational aims or lack of it in representations of borders of the Romanian nation and of Romanian territorial identity, as reflected by Geography school textbooks, considering the sixteenyears before the Great Union, and the interwar period, and then the creation of socialist Romania (for the last one, see the exploratory research of Ilovan, Bagoly-Simó \& Herbstritt, 2018). By studying the discourse of the borders of Romania in Geography school textbooks, one may identify stereotypes regarding the nature, culture, and people of Romania (Caramelea, 2015).

\section{STATE OF THE ART}

This section includes the theoretical background, discussing the most relevant contributions on the topic of school textbooks and state promoted ideologies. The school textbook is one of the most efficient channels to transmit political discourses towards the society, especially in the case of History textbooks (Mârza, 2015, p. 1035), but research showed that Geography textbooks were used just as much for propaganda purposes (Hajdú \& Paasi, 1995; Ilovan, Bagoly-Simó \& Herbstritt, 2018; Paasi, 1999). Bagoly-Simó (2013) points out that "school geography textbooks reflect the social norms, values, and priorities of their places of publication" (p. 108), they reflect relationships among ethnic groups and constructions of Otherness (Hajdú \& Paasi, 1995; Kim \& Ryu, 2014; Paasi, 1999; Pagliarini de Souza, Drigo \& da Silva, 2015). Other articles related to school textbooks discussed in detail the topic of maps and their geopolitical role (Rumiantsev, 2010). The role of visual materials in forming symbolical images about space has already been researched for textbooks focusing on representations of the nation (Fedotova, Latun \& Okuneva, 2014; Kennedy, 2020; Kučerová, Kučera \& Novotná, 2018; Ilovan, Bagoly-Simó \& Herbstritt, 2018), on representations of borders and identities (Silova, Yaqub \& Palandjian, 2014), and, in general, on the topic of geographical knowledge as a social construct (Kim \& Ryu, 2014).

Paasi (1999) considers that it is a crucial task for academic geographers to analyse school geography textbooks so that we can understand the construction of socio-spatial representations that influence the way we act: "The knowledge and truth that was mediated to children in schools was [...] politically and socially laden" (Paasi, 1999, p. 17).

Besides research on geography and history school textbooks, the concept of 'structures of expectations' (Paasi, 1986, 2003, 2009) has been useful for my research because it helps to unveil the geographical framework of studying the relation between past and present and this 
is true also in representations of the state borders and for the creation of regional and national imagined communities:

"Regional consciousness points to the multi-scalar identification of people with those institutional practices, discourses and symbolisms that are expressive of the 'structures of expectations' that become institutionalized as parts of the process that we call a 'region'." (Paasi, 2003, p. 4).

"As Lowenthal $(1985,40-41)$ points out, the past is integral to our sense of identity, it validate s present attitudes and actions by affirming their resemblance to former ones" (Paasi, 1999, p. 22).

Imaginations about space, nation and its borders have an impact on how people experience places (i.e. their nation is more imagined and less experienced than place) (cf. Hajdú \& Paasi, 1995; Mârza, 2015; Paasi, 1999; Silova, Yaqub \& Palandjian, 2014). These representations give people a sense of a shared history and experience, impacting on their group identity, on their imaginations of the nation and its borders (cf. also Entrikin, 2018, p. 44). However, referring to historical narratives about the past, not simply inventions or representations imposed on the past, some are more plausible than other (Fulbrook, 2002).

As Caramelea (2015) shows, present day features of the uniqueness and authenticity of Romania were discoursively constructed at the end of the $19^{\text {th }}$ century and the beginning of the $20^{\text {th }}$, supporting thus the argument that certain representations are transmitted from one generation to the next. In her article on the relationship between ideology, national identity, and the content of Geography textbooks, for the period between 1864 and 1945, Caramelea (2015) explains how the language and images in her research material convey political and cultural messages, as part of the project to build Romania as a national state and its national identity:

"Allied with history and politics, geography brought its contribution to the national identity building, constructing an exceptional place, 'unique and authentic' to be inhabited by the nation, a historic and ancestral land - Romania" (Caramelea, 2015, p. 155).

An earlier study in textbooks focused on education in Transylvanian schools between 1850 and 1870 (Ianoş, 2010). In addition, previous research on representations in Geography of Romania school textbooks showed that the visual discourse of the communist propaganda impacted upon geographical education about the nation (cf. Ilovan, Bagoly-Simó \& Herbstritt, 2018).

A variety of scientific approaches related to the formation of imagined communities of any type were considered within the framework of the constructivist theory of culture, including the following: identity construction (Cerulo, 1997), social construction and identity politics (Gergen, 2000), the discoursive construction of national identities (De Cillia, Reisigl \& Wodak, 1999; Ricoeur, 1991; Terlouw \& Van Gorp, 2014; Terlouw, 2017; Wodak et al., 1999), the construction of national history (Hooson, 1994; Newman \& Paasi, 1998; Nogue \& Vicente, 2004) and of national identity based on myths (Boia, 1998, 2011). Equally important were the following topics that created the theoretical context of my research: regional geographies and ways of researching the production of space (Ayres, 2018; Entrikin, 2018; Huggins \& Thompson, 2018; Jessop, 2018; Jones, 2018; Paasi, Harrison \& Jones, 2018), and regions as social constructs (Paasi, 1991, 2010, 2013, 2019; Paasi \& Metzger, 2017).

The potential of images to communicate and popularise dominant ideologies is researched in connection to the role of textbook ideology in the social reproduction of certain values (Babaii \& Sheikhi, 2018). Textbooks have the following features: "an abundance of subtle, embedded 'lessons' for children on issues of political, social, and national socialization" and they "contribute to the construction of 'official knowledge,' including a shared system of beliefs and values that help create a 'national culture'." (Silova, Yaqub \& Palandjian, 2014, p. 109; cf. also 
Mârza, 2015). According to the representational reading, images are used for inscribing particular realities (Pongajarn, Van der Duim \& Peters, 2014, p. 6).

In addition, the interdisciplinary approach of my research methodology, with its advantages of tackling overwise fluid concepts is difficult to restrict to a certain knowledge field (Weingart, 2000; Weingart \& Stehr, 2000). Therefore, my research is part of the cultural studies concemed with discourse analysis and concepts such as language, image/representation, power, ideology, and identity, as well as with discourse in building regional identities (Gruffudd, 1995; Sabău, 2015; Sabău \& Ilovan, 2019; Sabău \& Onofreiu, 2020), with discourse and representations of reality (Potter, 1996) and with Otherness in ideological representations (Oktar, 2001). I argue that the official discourse of geographical education, based on textbooks, had an ideological and political component and aim. The political component of the geographical discourse consists of its legitimation arguments concerning the Romanian state borders:

“[...] in order to distinguish the political component of a discourse from the multitude of its other components (heuristic, ludic, informative), it is necessary that the discourse fulfils one or more of the following strategic functions: a) coercion; b) resistance, opposition, and protest; c) dissimulation; d) legitimation and delegitimation" (my translation, Morar-Vulcu, 2007, p. 31).

Within this theoretical framework, the representation is the core concept in this article. In these pages, I advocate for the centrality of representations in shaping our lives and our perception of space and place (Anderson, 2019). As such, my research is part of the present trend in New Cultural Geography (cf. Anderson, 2019; Dubow, 2009; Hall, 1997a, 1997b; Mitchell, 1994, 1998, 2004; Rose, 2014), referring to the need to "understand the forces of representations as they make, remake and unmake worlds" (Anderson, 2019, p. 1). According to Söderström (2010, p. $11, c f$. also llovan et al., 2019, p. 60), the quality of the representation to be a "boundary notion" ensures its potential for innovation in various fields, in direct relationship to the process of knowledge production. The "crisis of representation" of the 1960s and 1970s consisted of a sustained critique of the notion in Arts and Humanities, and it was followed by the development of the non-representational theory and geographies, whilst the 1990s brought about the "visual turn" with the salience of vision and visual methodologies in research (Banini, 2019, 135-181; Hall, 1980; Rose, 2014; Söderström, 2010, pp. 13-14); my research draws on this visual turn in Cultural Geography.

Considering plural and open to contestation pedagogies of space, Silova, Yaqub and Palandjian (2014, p. 106) discuss how educational narratives based on visual imagery contributed to spatial socialisation through the theoretical lens of the "pedagogy of space":

\footnotetext{
"Newman and Paasi (1998) conceived the 'pedagogy of space' as the process through which institutional 'discursive landscapes of power' infuse the national space-whether understood as the country's borders or its geographic landscape-with certain cultural, social, and national meanings (p. 196). Here, an emphasis on discursive power is important; it is precisely the concept of discourse as power that we may most readily associate with the term pedagogy. Far from a merely objective, value-free field of discourse, school pedagogy is bound to the political, social, and cultural order, embedded in and establishing fields of power. Similar to Popkewitz's (2010) more general articulation of the notion of 'pedagogy,' we may consider educational pedagogies of space as political as well, working to fashion thought about the spatial: about what it is and should be, and 'about what is cast out and excluded from these normalized spaces' (p. 16)" (Silova, Yaqub \& Palandjian, 2014, p. 106).
}

Therefore, in my research, I consider that the truthfulness of representation in "rendering" reality is put aside. After the crisis of representation, the focus is now on studying representations in context (political, social, cultural, and economic). One such representation 
with a central role in geographical research is the landscape, which is a socially produced construct, a spatial representation, and a discourse about reality. Reality is represented through word-text and images and these create identities. When public opinion acknowledges them, these identities are becoming stereotypes or stereotypical representations: "[s]tereotypesmay be defined as simplified beliefs" (Hajdú \& Paasi, 1995, p. 35). Because territorial identity is constructed through political and social action, the context of producing representations is always relevant, as it has political, social and cultural implications (Haraway, 1998). Thus, identity is narrative (Anderson, 1983). By looking at the construction of identity through the circulation of certain official representations (i.e. in school textbooks), I discuss an identity that is imposed from above (on individuals, on groups, on places).

\section{METHODOLOGY}

The methodology section is divided in two parts: (1) Research material. Data collection and (2) Methods. Data analysis and interpretation.

\section{Research Material. Data Collection}

The research material consists of Geography of Romania school textbooks. I collected visual and narrative representations from five primary sources: two school textbooks on the Geography of Romania, one published in 1902 (second edition) and reedited in 1905, 1910, 1916 (Murgoci \& Popa-Burcă, 1902, 1905, 1910, 1916) and one of 1935 (Gheorghiu \& Simionescu, 1935, the second edition of a geography textbook from the interwar period). These are all for the 8 th grade (lower secondary education) (Figure 1 and Figure 2). I selected these textbooks because I started from the premise that they were circulated in the education system and in the public space as identity building and nation building resources.

Images are introduced into geography school textbooks of the Romanian territory at the end of the 1880s (cf. Caramelea, 2015, p. 174), that is why I chose textbooks for the first decades of the $20^{\text {th }}$ century, to be able to analyse both powerful visual representations, such as maps, and linguistic accompanying ones. Moreover, it is well-known that borders are best represented through maps and that they can communicate an articulate message just through one image (cf. Fall, 2006).

However, all images referring to the state borders of Romania, from these textbooks (i.e. not only the maps) were considered and thoroughly analysed, because of their visual impact upon students and due to their messages. A partial answer to my research question was given by the written texts accompanying the visual material. From these sources, any quoted texts are translated from Romanian into English.

Furthermore, historiography adapts its discourse, and this is rather uniform in the first decades of the $20^{\text {th }}$ century, as it was considered that the Great War had solved one major problem: the creation of Greater Romania. That is why I chose school textbooks published during this period. Then, during the interwar period, there was no ideological or political line that textbooks were compelled to observe, the school curriculum being the only imperative (Mârza, 2015, p. 1038). 


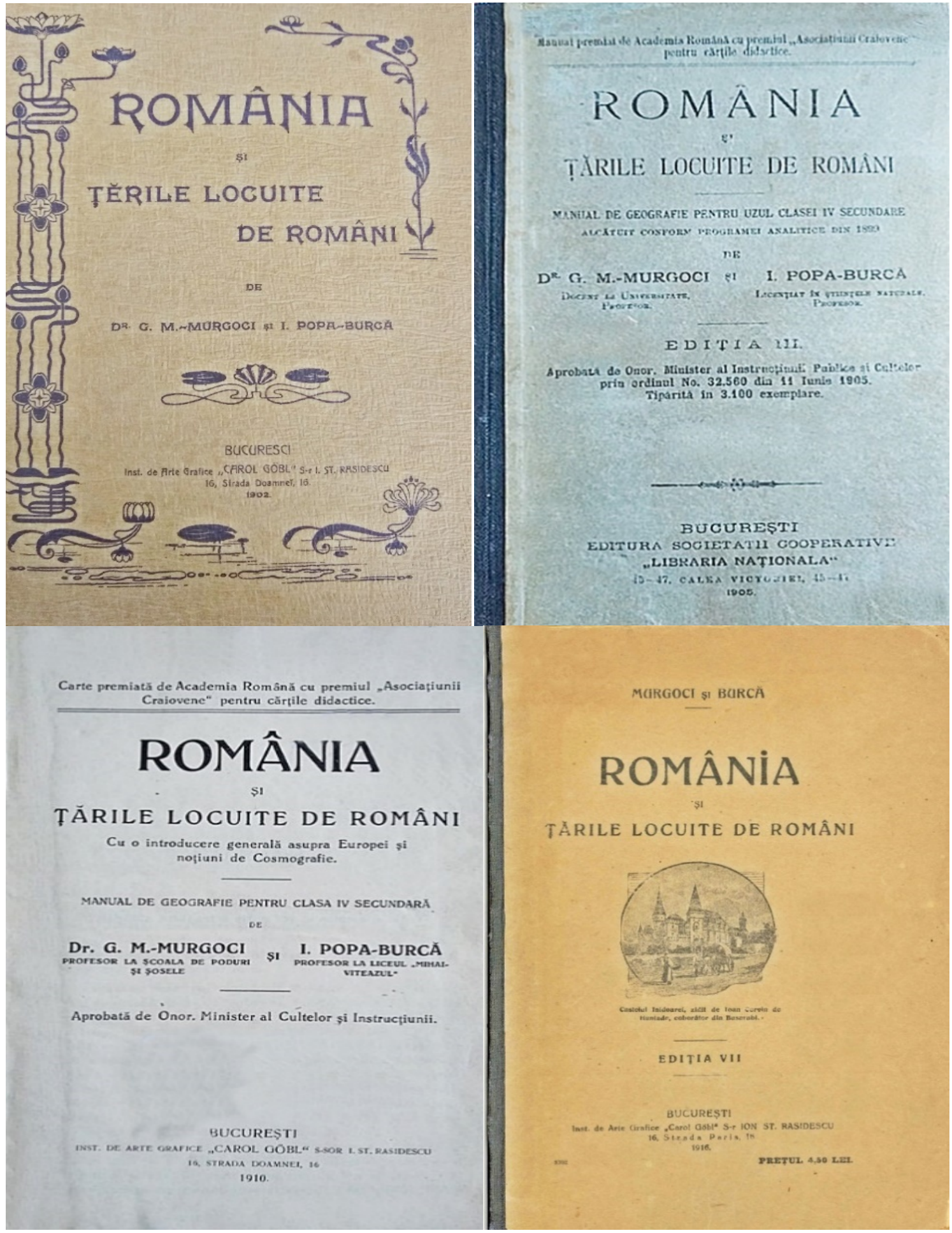

Figure 1: The four chosen editions of the school textbook on the Geography of Romania and of the lands inhabited by Romanians 


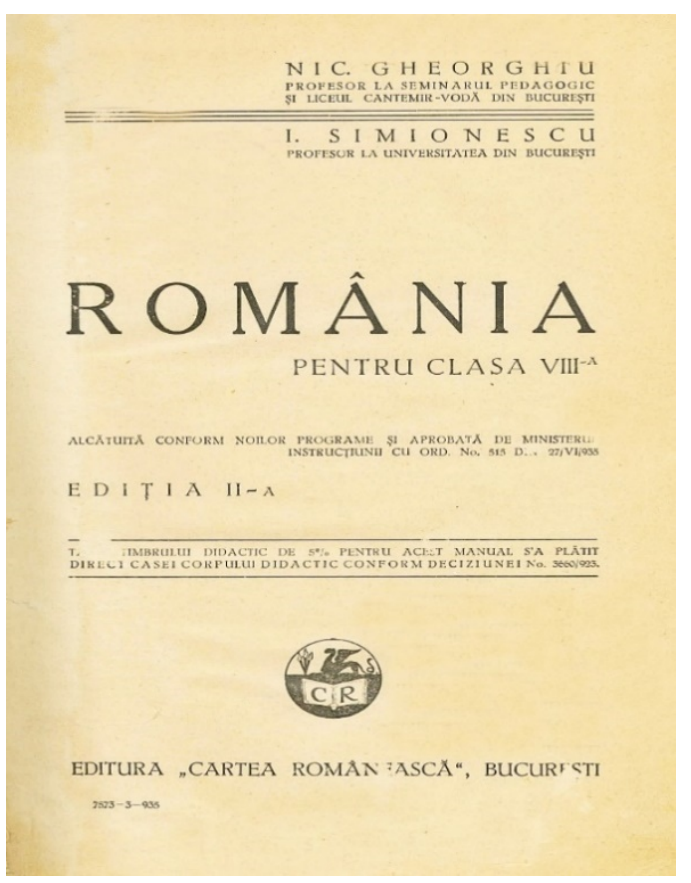

Figure 2: Interwar school textbook on the Geography of Romania, for the last year of lower secondary education Source: Gheorghiu \& Simionescu, 1935

\section{Methods for Data Analysis and Interpretation}

For analysing and interpreting the visual discourse about borders in Geography of Romania textbooks in the first four decades of the $20^{\text {th }}$ century, I used discourse analysis (cf. Ilovan, 2020; Mattissek, 2010, 2018; Mattissek \& Glasze, 2014) of the visual and the written text, as well as visual analysis (cf. Rose, 2014). For my interpretative framework, the semiotic approach (de Saussure, 1986) was particularly useful when using both discourse analysis and visual analysis, as my first step consisted of identifying, in word-text and visual imagery, certain relevant signs/symbols for my research topic (i.e. the Romanian nation in relation to its borders), their signifieds (concepts or objects), the signifiers (the sounds or images attached to the signifieds) and referents (the actual objects in reality) (for a detailed discussion, $c f$. Ilovan, 2021; llovan \& Merciu, 2021).

From a methodological perspective, my emphasis is on the relationship between the concepts of knowledge, power, discourse, and space (cf. Foucault, 1971, 1986a, 1986b) and the need to deconstruct the taken for granted visual imagery, especially in the form of maps (cf. Crampton, 2001; Dodge \& Perkins, 2015). Here, space is produced and reproduced through representations and the creation of spatial imageries during a certain time frame, not just through people's perceptions and daily practices ( $c f$. Lefebvre, 1991).

\section{RESULTS AND DISCUSSION}

Geography is a visual discipline. In this part, I analyse how the Geography of Romania school textbooks depicted, through images, the national territory, and Romania's territorial identity, starting from a discussion on how its borders were represented. Maps, drawings, charts are 
representations of geographical knowledge and views upon an area, often imbued with messages stemming from the political power: "Pictorial images carry multiple meanings, and their interpretation involves both aesthetic and political judgements" (Jackson, 1992, p. 98, cited in Paasi, 1999, p. 15). These images were also significant tools in constructing Romanians' representations of their national territory and its state borders. Therefore, in this section, I present and discuss the educational discourse about the physical and cultural borders of Romania, as constructed by image- and word-text representations.

\section{Dacia ... Everlasting}

The surface and the borders of Romania form the first topic in the 1902 edition of the first analysed textbook (Murgoci \& Popa-Burcă, 1902); the territory inhabited by Romanians in Europe is represented by showing their distribution on a map. This is contrasted, on the same map, with a "black stain" (phrase used in the original text) which is Romania. The reader is thus able to see that the surface of Romania is much smaller than the one inhabited by Romanians (cf. figure 3 in Murgoci \& Popa-Burcă, 1902, p. 7), a fact repeated in the following editions (e.g. "The population of Romania. The number. Today, the Kingdom of Romania is inhabited by almost $8,000,000$ inhabitants; according to this, it is the $10^{\text {th }}$ state of all European states", Murgoci \& Popa-Burcă, 1916, p. 80, my translation).

The map of the 1916 edition repeats the first figure included in the previous editions (Figure 3 ). Romania is envisioned as a nation state, where the borders should comprise the entire nation, meaning that no or not many Romanians should be left outside those borders. The nation is perceived as inherited, not a social or historical construct, and thus the borders of the nationstate should be those of Dacia. The imagined space of former Dacia is invoked through a specific geographical setting: delimited by three rivers and a sea. The key and "natural" ("normal") borders of the Romanian people are the Dniester, the Tisza, the Danube, and the Black Sea. Representations of Dacia's borders are foregrounding, according to the authors of these textbooks, the essence of Romania, they are reflecting its original boundaries, constantly threatened, and changed during history. The dream is to recover that first, original, and ideal situation and boundaries, with their present "quasi-legendary status" (Fall, 2006, p. 658).

The aim of the Great War, according to these authors, is to gather all Romanians (or most of them) within the future state borders of Romania, which, hopefully, would be exactly those mentioned above. That is why the textbook uses the syntagm: "Romanian land" and not Romania, the latter still comprising only Wallachia, Moldova, and Dobrudja" (Figure 3):

"The position and extent of the Romanian land. The most significant part of our people occupies the region of Central Europe, between the Dniester, the Tisza, the Danube, and the Black Sea. This territory covers over $300,000 \mathrm{~km}^{2}$, more than the surface of Italy and England, and it shelters more than 13,000,000 inhabitants" (Murgoci \& Popa-Burcă, 1916, p. 5, my translation). 


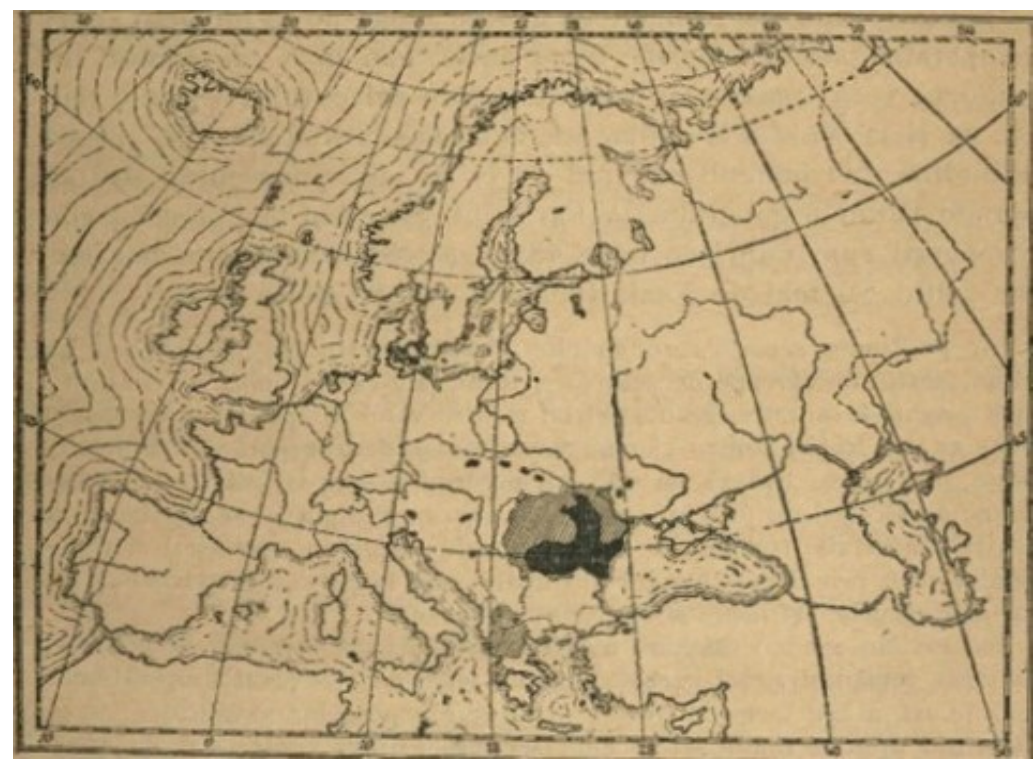

Figure 3: "Romanians in Europe"

Source: original title in Murgoci \& Popa-Burcă, 1916, p. 5

The next figure is the one titled "Borders of Dacia and Romania; the included provinces" (Murgoci \& Popa-Burcă, 1902, p. 14, Figure 4, left). From this map and also by having the information from the previous figure (Figure 3), the reader understands that the surface of Dacia best overlaps the territories inhabited by Romanians. Romania, in 1902, included four provinces: Oltenia and Muntenia (these two forming Wallachia), Moldova and Dobrudja, while Bessarabia belonged to Russia, and Bukovina, Maramureş, Transylvania, Jara Crişului and Temişana belonged to Austro-Hungary. The message is that Dacia can become a reality again when all the provinces then underforeign rule are part of Romania.

The 1905 edition of this textbook reproducesagain the map with the Romanian provinces, titled "The division of the Romanian territory into provinces" (Murgoci \& Popa-Burcă, 1905, p. 17). The map is identical to that in 1902 (Figure 4, left), only its title is changed. The new title does not refer to historical Dacia any longer, but it is replaced with the stronger "Romanian territory."
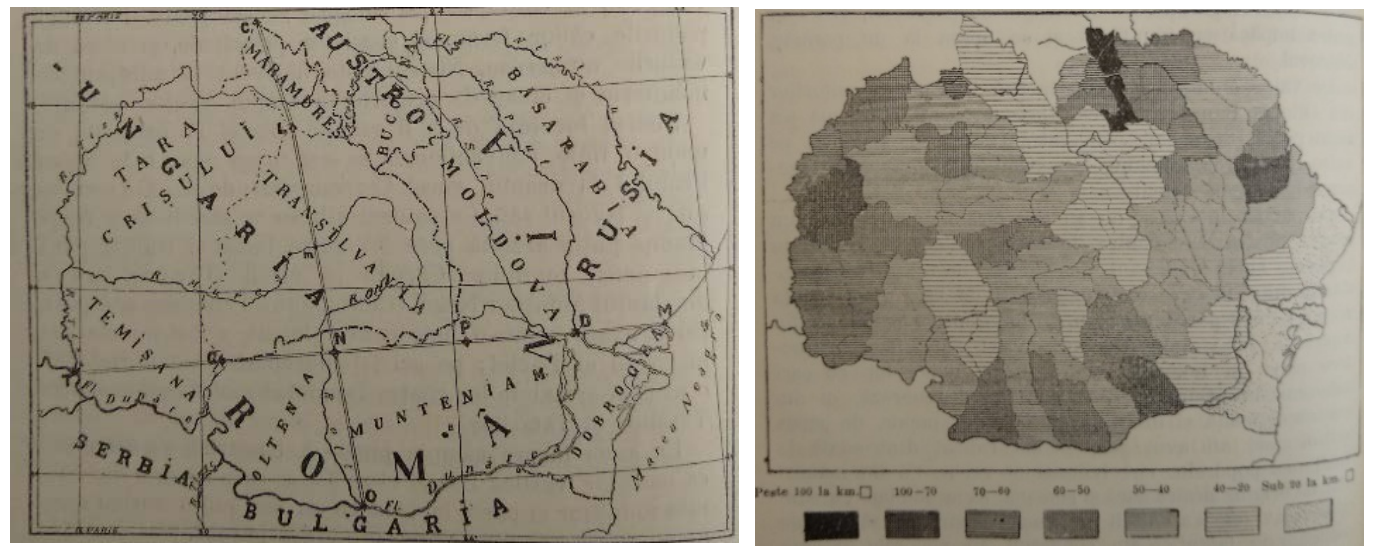

Figure 4: "Borders of Dacia and Romania: the included provinces" (left); "Density of population between the Dniester and the Tisza" (right) 
The lands inhabited by Romanians under foreign rule are Bessarabia, Bukovina, Transylvania, the Banat of Temişana, The Land of the Criş and Maramureş (Murgoci \& Popa-Burcă, 1902, p. 314). Transylvania, Bukovina, and Bessarabia are described also through a new entry in the contents, in comparison to the other provinces: that of the nationalities, because they are ethnically diverse. These geography textbooks tackled the subject of Romania's borders from the beginning, in the attempt to familiarise students with the geographical position of Romania within Europe, but took this topic much further, with a detailed presentation and pros and cons related to the fairness of these state borders (Murgoci \& Popa-Burcă, 1902, pp. 7-14; Murgoci \& Popa-Burcă, 1916, pp. 6-7).

The restoration of Dacia is a leitmotiv of representations in the maps of these textbooks (four editions) (see Figures 4 and 8). "The Romanians outside Dacia" are those in Turkey (Macedonia), Serbia and Bulgaria, the ones beyond the Dniester, in Galicia, in Istria, Carinthia, Dalmatia, Croatia, and in Bosnia (Murgoci \& Popa-Burcă, 1902, p. 315). Dacia is again the geographical and historical reference system for the areas inhabited by Romanians and living under foreign rule. The distribution of population in the region between the Dniester and the Tisza, the territory of Dacia, as represented in Figure 2, as well as in Figure 42 of the 1902 edition of the textbook (cf. Figure 4) is meant to be the second argument, the ethnic one, besides the natural/physical borders. Despite the features of geographical information provided in any school textbook, there is an insistence on the number of inhabitants and the distribution of population which is obvious in the 1916 edition, but this time featuring only the territory of Romania (Figure 5).

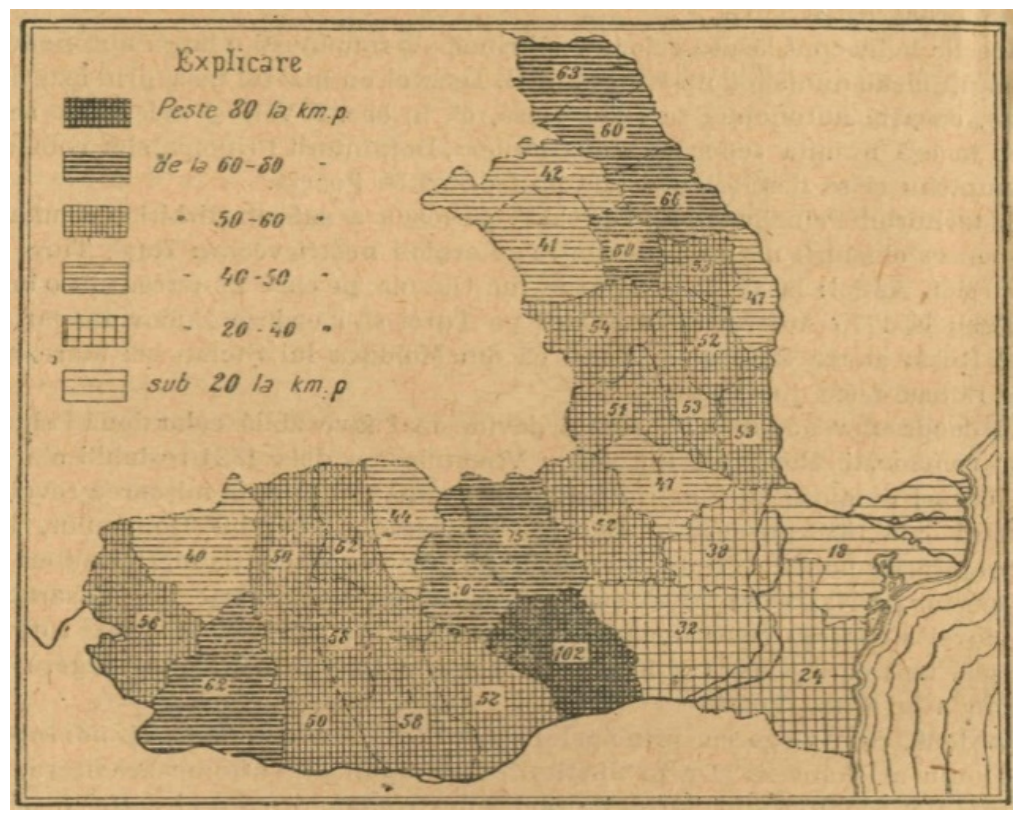

Figure 5: "Density of Romania's population" Source: original title in Murgoci \& Popa-Burcă, 1916, p. 80

Dacia's borders are still the landmarks that point out the areas inhabited by Romanians, while in 1916, upon entering World War I, Romania included only half of the territory inhabited by Romanians. So, the ethnic argument is considered paramount in any type of bordering, and the Great War was such a process:

"The Romanian people is divided among several states. The Romanians are spread on a larger surface than that of today's free Romania. The Romanian language can be heard in the entire region called Dacia in the past and even further to the south and east, so that the areas inhabited 
by Romanians beyond the borders of the kingdom are as large as the kingdom itself" (Murgoci \&

Popa-Burcă, 1916, p. 3, my translation).

The typical Romanian is represented as the Romanian peasant (cf. also his description in Gheorghiu \& Simionescu, 1935, p. 161). The textbook advertises an essential identity: "the Romanian is the same everywhere". Romania's exceptionalism and the homogenous features of Romanians, no matter where they live, are two of the much-visited topics in the textbook of 1916 ( $c f$. also Caramelea, 1915, for a demonstration of the same idea, based on Geography textbooks within the period 1864-1945):

"Romania is an ethnical entity as there is no other in Europe. The Romanian is the same everywhere; The Romanian in Maramureş or in the Timok Valley, that in Bessarabia like the one in the Bihor Mountains are alike in behaviour and mind, they have the same customs and speak the same language as the Romanian in our country, like true brothers" (Murgoci \& Popa-Burcă, 1916, p. 166, my translation).

Students' geography and history knowledge about Romania and the other areas inhabited by Romanians is structured through representations of Dacia and a set of expectations are produced this way. The maps maintain the region of Dacia visible and encourage students to believe that its future will be fulfilled under a different name: Greater Romania. Such imagery is a powerful ideological tool either in geography and geopolitics or in geographical education. These representations are used to enable students' "spatial socialization" and to form cohorts of citizens of Romania willing to fight and sacrifice for their nation and to defend its natural or original borders.

Much attention is paid to the description of borders in the 1916 edition of the textbook. Here, the authors differentiate between Romania and the territory inhabited by Romanians. The language is crucial for deciding the state borders: "the re-uniting of all Romanians within a single country, the re-birth of Greater Romania, with larger borders, as far as the Romanian language can be heard" (Murgoci \& Popa-Burcă, 1916, p. 5, my translation). The borders are natural elements (i.e. rivers) or conventional lines. Irrespective of their nature, borders are assessed based on their defence function. They are strong or weak and tested during the war history of the Romanian provinces:

"To the north, Romania does not reach the Dniester, but the Prut is the border on a short distance, then there is a conventional line towards the south, to the Siret Valley, at the confluence of Suceava. From here, a winding border goes towards the west, over the Moldova river, over the peak of the Rarău Mountains, to the Bistriţa Valley, from where the borderline climbs the summit of the Carpathians, to the Călimani Mountains. In this part was the weakest border of our territory, even when Moldova included Bukovina and Bessarabia; here the Poles led their troops, with no obstacle whatsoever, against the rulers of Moldavia, and against the Turks and the Tartars" (Murgoci \& Popa-Burcă, 1916, p. 7, my translation).

The changing nature of borders when these are the landforms is emphasised: they may unite or divide the same people. At present, landforms still divide (e.g. the Carpathians, the Prut river):

"From the dawn of history, the branches of the Romanian people did not come together because of the places they live in: mountains, hills and fields. Especially in the past, the high mountains and the big rivers were an obstacle to the unity of the people sharing the same blood, because these were considered borders between countries although the people were the same one on both sides of the border" (Murgoci \& Popa-Burcă, 1916, pp. 3-4, my translation).

"From all this land inhabited by Romanians, free Romania includes over $139,000 \mathrm{~km}^{2}$, which is two fifths, while the rest is under the rule of Russia that we neighbour to the north-east and of AustroHungary, our neighbour to the north-west"; "To the north and west, Romania is separated by 
Austro-Hungary by the chain of the Carpathians, which now rises as a two times and three times dividing wall among brothers, even if in the past it was our shelter" (Murgoci \& Popa-Burcă, 1916, pp. 6-7, emphasis in the original; my translation).

"To the east, Romania is a neighbour of Russia, from which it is separated by the river Prut, and this splits in two somewhat equal parts the territory between the Carpathians and the Dniester" (Murgoci \& Popa-Burcă, 1916, p. 7, my translation).

The story about the liberation of those affiliated through blood and language is presented in a series of historical dramatic and glorious events, within the borders of a centuries-long imagined community in a beautiful homeland: Michael the Brave "coagulated Dacia again" and the Roman Empire and our ancestors influenced the Romanians' blood and character (Murgoci \& PopaBurcă, 1916, p. 4).

The reader can follow the various territorial changes of the provinces included in the 1910 edition of this textbook, showing Romania and its neighbours over four centuries, starting with 1600 (Figure 6), an idea repeated in the 1935 textbook (Gheorghiu \& Simionescu, 1935, p. 191, cf. Figure 17 of this article).

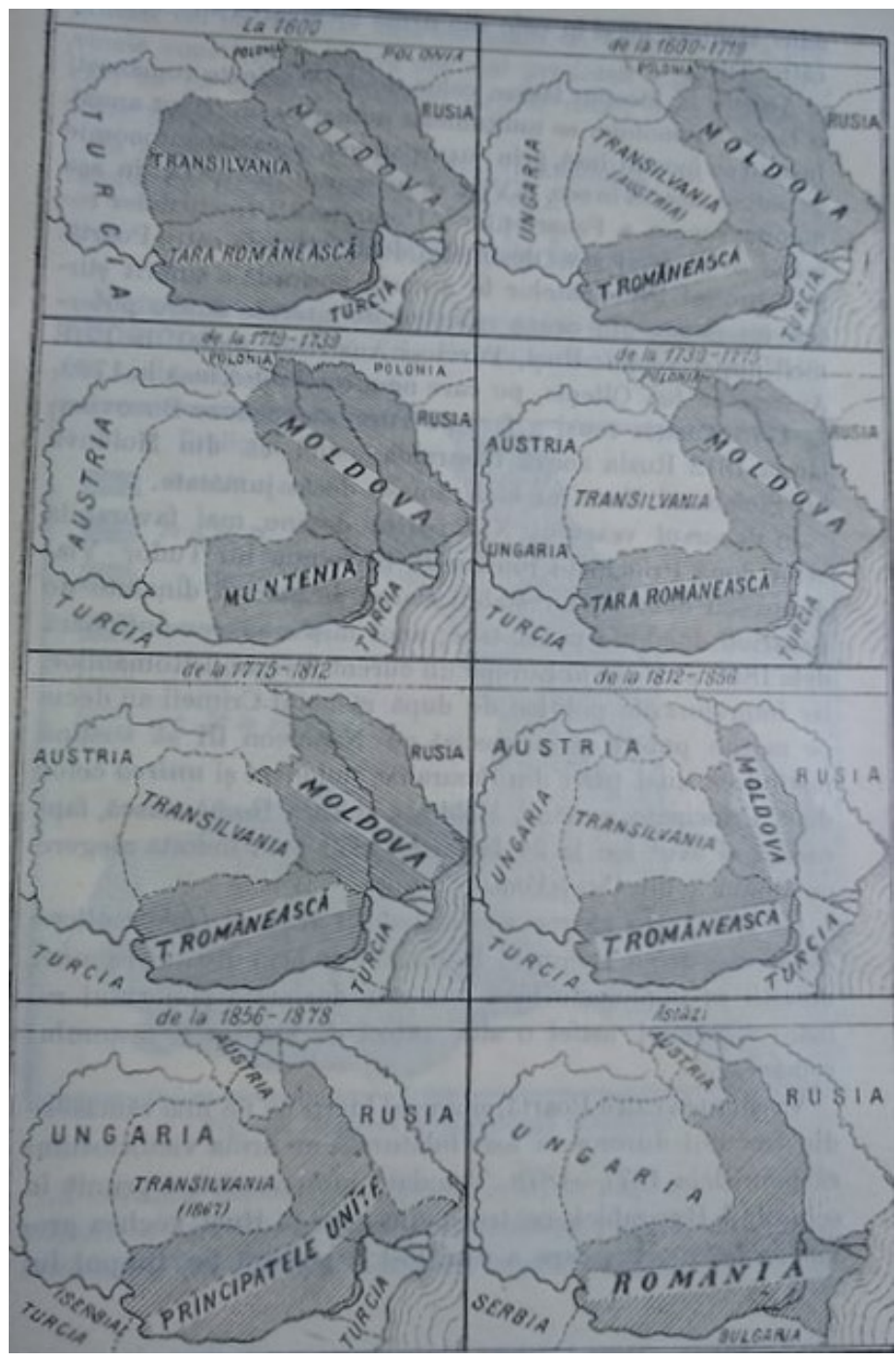

Figure 6: "Various territorial changes of the two Romanian principalities, from 1600 to present"

Source: original title in Murgoci \& PopaBurcă, 1910, p. 101

However, the authors' insistence on representing the territory bordered by the Dniester, the Tisza, the Danube and the Black Sea is preferred in the two large maps: the physical map of Romania (Figure 7) and the ethnographical one (Figure 8). 
Figure 7: "Physical map of Romania and of the lands inhabited by Romanians"

Source: original title in Murgoci \& Popa-Burcă, 1916, map

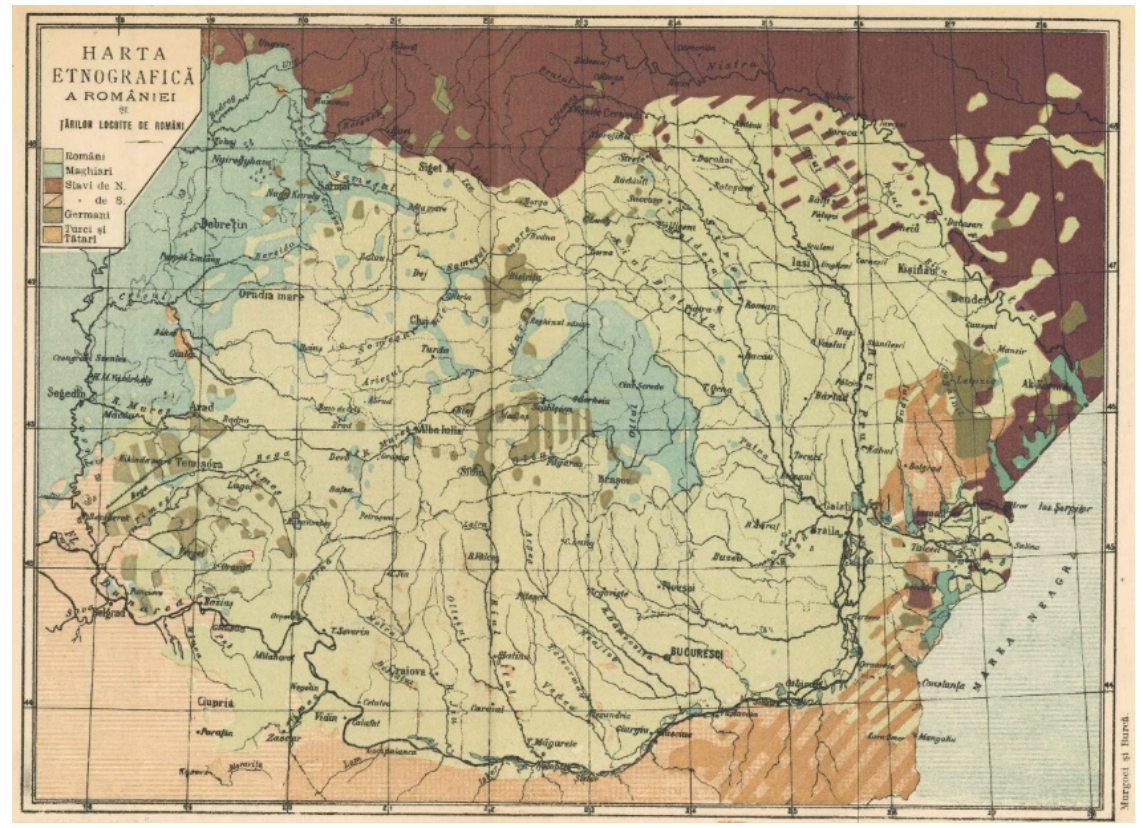

Figure 8:

"Ethnographical map of Romania and of the lands inhabited by Romanians"

Source: original title in Murgoci \& Popa-Burcă, 1916, map

In the text accompanying the ethnographical map (Figure 8), authors underline the swift changes that may appear because of the ongoing war: "and the ethnographical map made based on these data might have changed quite a lot and will have further changed by the end of the war" (Murgoci \& Popa-Burcă, 1916, p. 2; cf. also Dulamă \& llovan, 2015, pp. 64-66). 


\section{Creating Greater Romania through the Geography School Textbook}

The changes in meaning in the case of these representations depend on the context (i.e. representations are time and context sensitive). Is there a determinism of the representations? In the 1916 edition of this textbook, the authors argue in the Preface that they hope the information (and representations) they provided for the educational system contributed to the mentality changes necessary to create Greater Romania (Murgoci \& Popa-Burcă, 1916, pp. 1-2). The 1916 edition of the textbook on the Geography of Romania registers the "great transformation" of the Romanian lands and as a result of the war aiming to form Greater Romania:

"we dare to believe that, through this book, we also contributed something to the creation of Greater Romania, we contributed with the necessary soul for its creation" (Murgoci \& Popa-Burcă, 1916, p. 1, my translation).

Ever since it was issued, the book had not merely educational, but also political and ideological aims, and it was reedited with the approval and appreciation of the Romanian Academy and of ministerial commissions:

"there are no Romanians who had attended the lower secondary grades to have missed having this book in their hands" (Murgoci \& Popa-Burcă, 1916, p. 1, my translation).

The aim of the textbook is stated clearly in the preface - to develop students' love for their country and people:

"Our colleagues who are teachers and our beloved students saw that this textbook began with underlining our national ideal 'the union of all Romanians in a single country, up to where the Romanian language is heard' and ended with the same idea: 'One should know that each lost Romanian is a rock taken down from the basis of our national ideal, that all Romanians are part of the same country'. And we have written this entire book like this, to develop the love for the country and for the Romanian people" (Murgoci \& Popa-Burcă, 1916, p. 1; emphasis in the original; my translation).

The emotional charge is obvious in the Preface. The authors underline that their textbook is a radiography of the situation of all areas or "lands" inhabited by Romanians before the making of Greater Romania:

"That is why this edition is so much more interesting; it is a document showing us the situation of the lands inhabited by Romanians before the Great War for uniting them all, in the eve of creating Greater Romania" (Murgoci \& Popa-Burcă, 1916, p. 2, my translation).

The textbook provides the young learner with information and representations of the nation's borders. The borders of the Romanian state are legitimised through the authors' convictions, as stated in the Preface to the 1916 edition (Murgoci \& Popa-Burcă, 1916) and convictions are based on feelings, not on data or logical processing of these.

The authors state that "all Romanians who are aware" are joyful (Murgoci \& Popa-Burcă, 1916, p. 1), a month after the Romanian army crossed the Carpathians, joining the war, aiming at "the union of the Carpathian Romanian lands" (Murgoci \& Popa-Burcă, 1916, p. 1). Soldiers' precious blood is shed for the "great work," and therefore Romanians are entitled to joy and discrete pride:

"From the $14^{\text {th }}$ of August 1916, we also entered the furious World War started by the Germans in the summer of 1914 and we walk with strong steps toward the creation of Greater Romania" (Murgoci \& Popa-Burcă, 1916, p. 1, my translation). 
The nation-state is presented as a collective ideal of the Romanians in the textbook of 1916. The authors acknowledge that since the middle of August, when Romania joined the war, certain changes in the contents of the textbook had been implemented:

"we had time to make small changes and completions imposed by the nowadays situation and according to our dreams, especially for the neighbouring lands, inhabited by Romanians" (Murgoci \& Popa-Burcă, 1916, p. 2).

For instance, the inability of textbooks to reflect the fast-changing borders and implicitly the undergoing processes of bordering for the Romanian provinces is acknowledged by the authors in the 1916 edition, underlining that textbooks cannot keep the pace with the fast territorial changes on the map of Europe during the Great War:

"Bukovina, the one which suffered the largest number of adversities in this war, is presented here as a former Austrian province, although now it is under Russian rule and we received news that soon it will enter under the Romanian administration. Transylvania and Banat are described, unfortunately, still as Hungarian provinces" (Murgoci \& Popa-Burcă, 1916, p. 2, my translation).

The textbook has a circular discourse: ideas from the Preface are revisited at its end. In the section of the textbook named "Incheere" [Ending], the authors reiterate the aim of the war. Through war, the Romanians want to "fix the borders of future Romania over the Carpathians and Bukovina and to create a Greater Romania, whose embodiment we can already see" (Murgoci \& Popa-Burcă, 1916, p. 167, my translation).

This future Romania is described as a big country (by surface and number of inhabitants), beautiful, with good people: "We notice that within the area circumscribed by the Danube, the Dniester and the Tisza, the Romanian population is compact and strong, exceeding 13 million, and only half of it is united into a free country, the Kingdom of Romania" (Murgoci \& Popa-Burcă, 1916, p. 166, my translation), with over $250.000 \mathrm{~km}^{2}, 15$ million inhabitants (out of which 12 million are Romanians), a beautiful one, with a praiseworthy people, and with an exceptionally favourable configuration (Murgoci \& Popa-Burcă, 1916, p. 167), with "sure border lines" (p. 168) and blessed by God (because of the good climate for agriculture and because of its underground resources), a superlative ethnic entity in Europe, homogeneous, as the Romanian is the same everywhere (appearance and character, traditions, language, friendly nature). National consciousness is awakened, as authors underline: "A country like no other under the sun and a united people with great future. God help us to create it as soon as possible!" (Murgoci \& PopaBurcă, 1916, p.168, my translation).

\section{About Twenty Years Later: Still Constructing Greater Romania}

The second analysed school textbook is the second edition of the one for the $8^{\text {th }}$ grade, authored by Gheorghiu and Simionescu (1935). Students are informed about Romania's position: "Romania lies in the middle of the European continent and it is a bridge between its westem and eastern parts" (Gheorghiu \& Simionescu, 1935, p. 5). A few pages later, distances from the Black Sea, the Adriatic Sea and the Baltic Sea as well as those from harbours are represented (Figure 9), in order to emphasise Romania's favourable position for commerce.

The inclusion of the map of Romania within the map of France (Figure 10), in order to compare their surfaces, is a very interesting choice (see title of Figure 10 below). The message of the representation tends to transgress the initial intention (that of comparing surfaces), as Romania seems to be part of or related to France also from other perspectives: such as cultural, linguistic, political (i.e. protected by France). France, according to the title of the figure, is second in surface 
to Russia. Those who chose to do this representation could have included Romania also within the borders of Russia, for the sake of comparison, which they did not (Figure 10). One reason for which Russia is not represented here and France was chosen instead could have been the lack of trust in Russia (which might not observe treaties and military agreements) and Romanians' fear towards it, which were leitmotifs present in the interwar history school textbooks (Mârza, 2015, p. 1040).

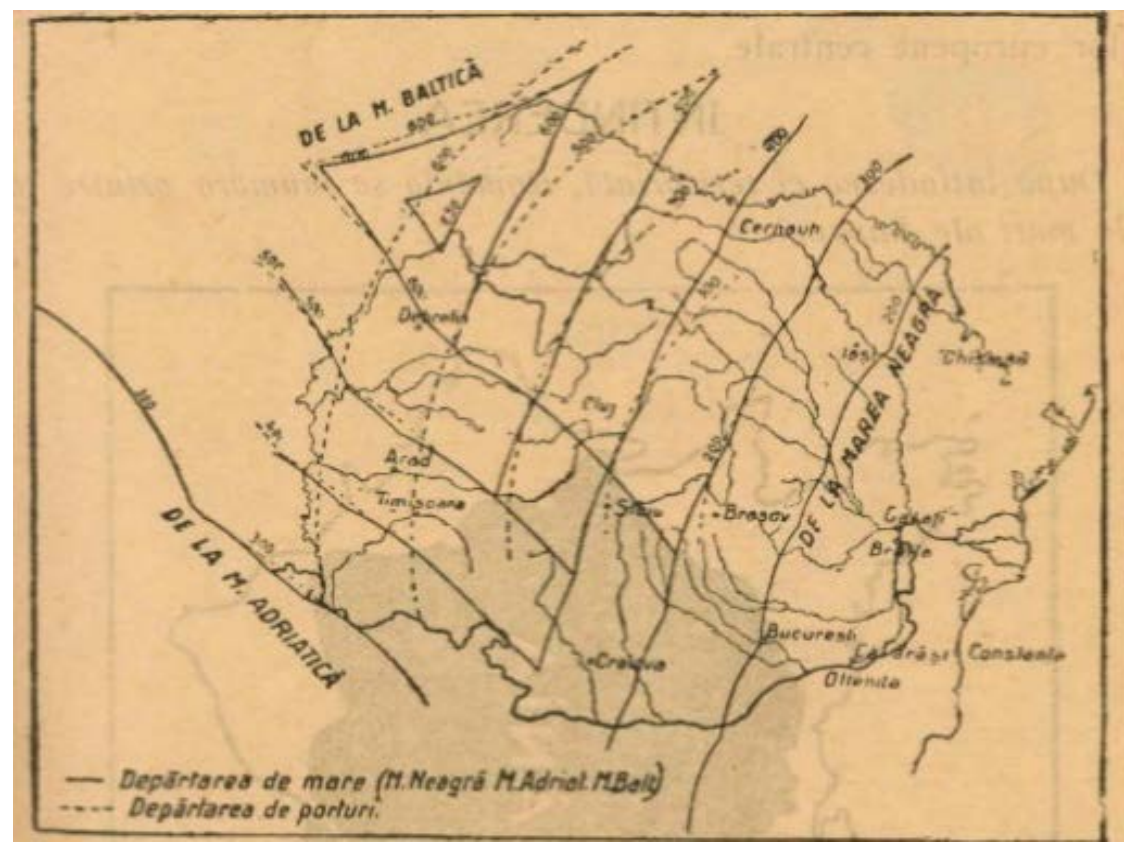

Figure 9: "Romania, at crossroads, has a favourable position for commerce"

Source: original title in Gheorghiu \& Simionescu, 1935, p. 11

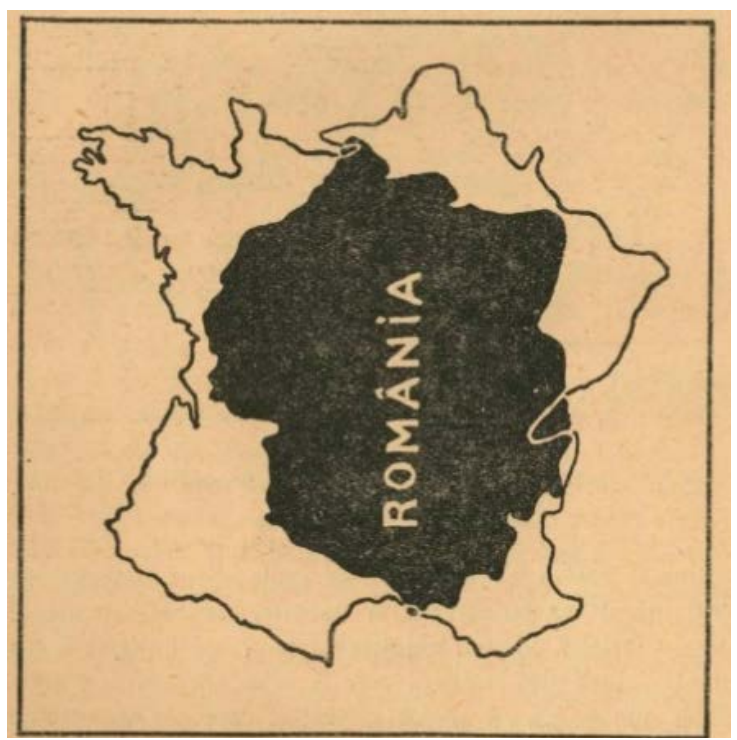

Figure 10: "As surface, Romania exceeds by half $(53 \%)$ that of France $\left(551,000 \mathrm{~km}^{2}\right)$ which is the largest country of peninsular Europe and the second after Russia from the entire continent"

Source: original title in Gheorghiu \& Simionescu, 1935, p. 12

From the title to Figure 11, it seems that Romania is in competition with its neighbours, by surface and number of inhabitants, while students are also informed that "by surface, Romania is among the big countries of Europe" (Gheorghiu \& Simionescu, 1935, p. 12, my translation). 


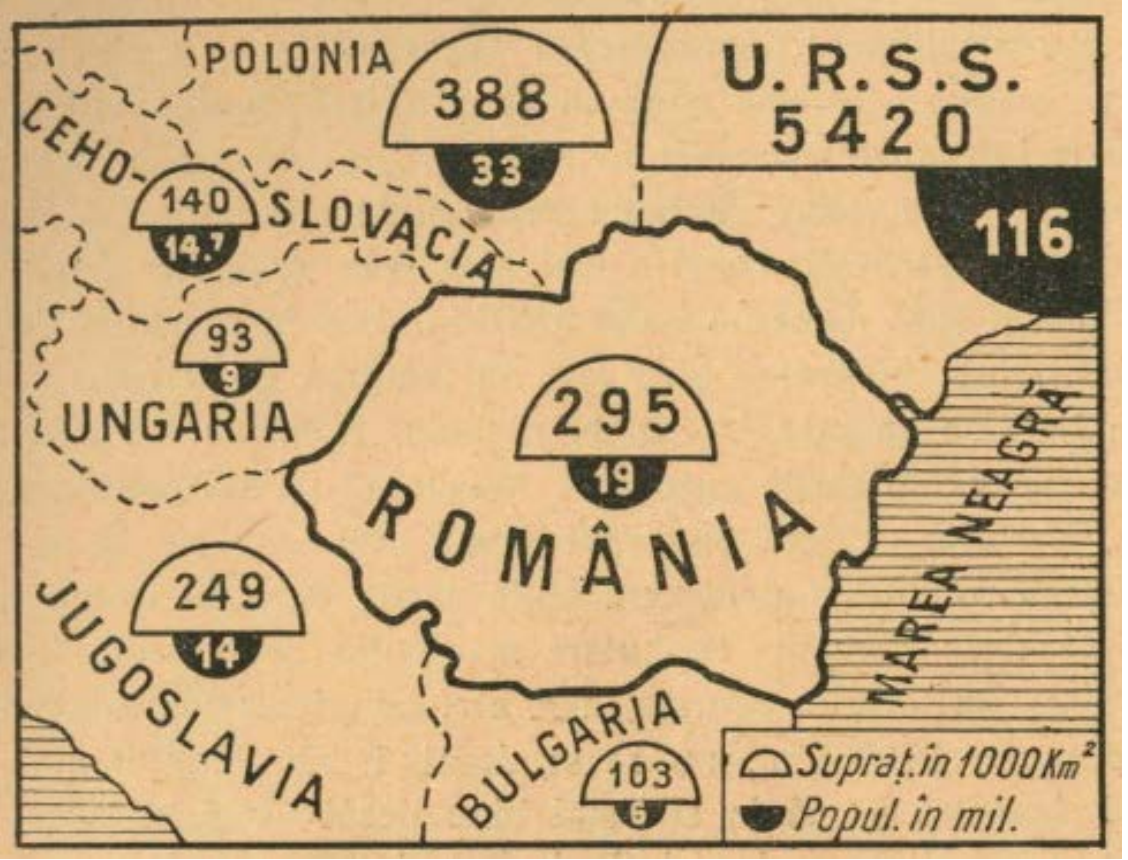

Figure 11: "Both as

surface and number

of inhabitants,

Romania is

outranked only by

two (Russia -

Poland) out of its six

neighbours"

Source: original title in Gheorghiu \& Simionescu, 1935, p. 13

Romania's borders are represented separately, mentioning their length and the neighbouring countries (Figure 12).

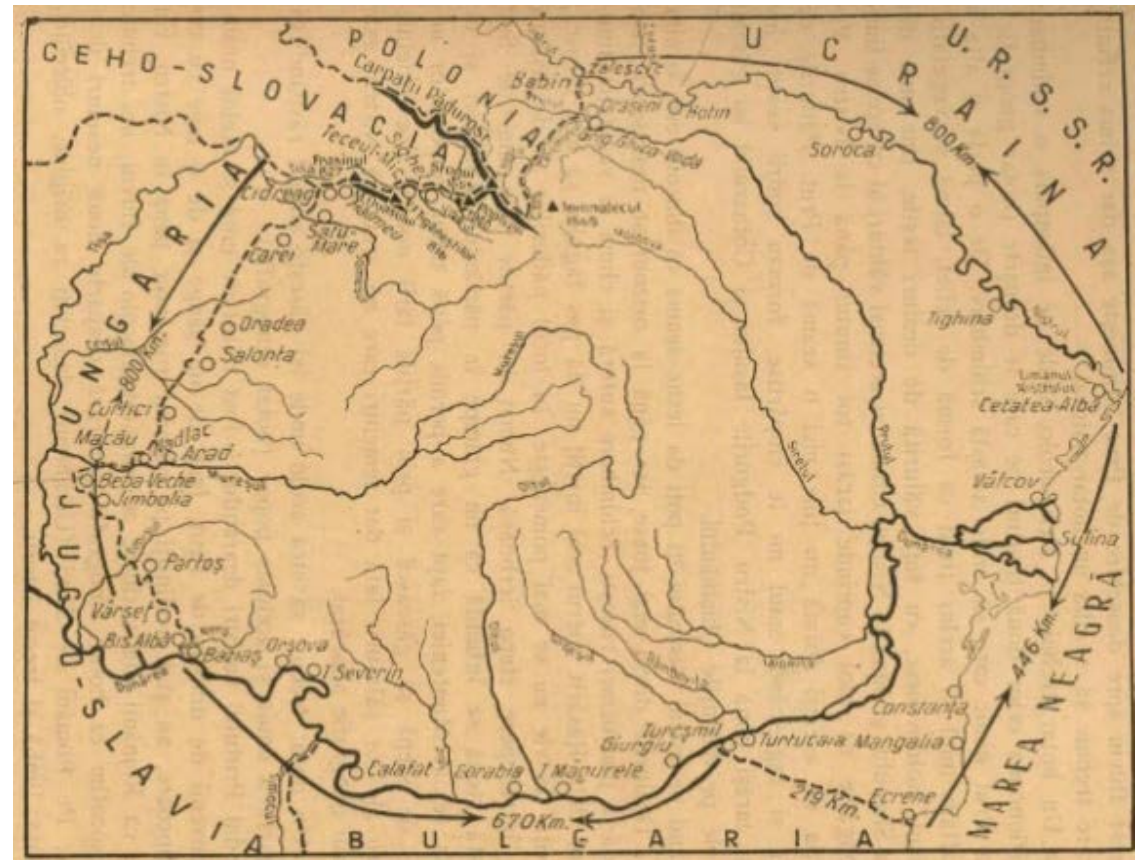

Figure 12: "The map of Romania's borders"

Source: original title in Gheorghiu \& Simionescu, 1935, p. 15 
The authors offer four reasons justifying the borders of Romania, in 1935, when the second edition of this second analysed textbook was published (Gheorghiu \& Simionescu, 1935, pp. 1516). It is interesting and relevant to notice the fact that the eastern border of Romania is discussed in detail, being used as a case study in order to improve the theoretical approach to borders (i.e. state frontiers) in general and thus students' geographical knowledge.

The first element introduced is that of the natural border and its features in order to be a steadfast one (i.e. "statornic" in Romanian). In this sense, two rivers are compared: the Prut and the Dniester. If the border would be on the Prut (thus the territory of Romania is diminished), Bessarabia is lost. The spatial imageries of the eastern border of Romania are discussed and authors point out: why should the Dniester and not the Prut be a natural border? The authors explain that, geographically speaking, the state border should be on the Dniester (thusincluding Bessarabia), because the Dniester has some features that recommend it to be a state border, unlike the Prut:

“a) A border has, first of all, to be a steadfast one.

The Prut, although smaller and poorer in waters compared to the Dniester, is a whimsical river. Considering its shallow riverbed, the low banks, together with a large river meadow where it walks its waters and breaks pieces of land from one bank or the other one, it lacks any steadiness. The Dniester, on the contrary, with its deep riverbed, dug into the hard cliff, displays high banks on a long distance and its waters follow the same route for thousands and thousands of years.

This river, in comparison to the Prut, fulfils thus the first request that a natural border should comply with" (Gheorghiu \& Simionescu, 1935, p. 15, my translation).

A change in the physiognomy of the territory (i.e. the landscape) is considered to be the second criterion for establishing a state border and the authors title this the geographicalborder:

"b) A border should be placed there where there is a change visible in the physiognomy of the two areas that it divides (geographical border)" (Gheorghiu \& Simionescu, 1935, p. 15, my translation).

Again, the areas divided by the Prut and the Dniester are compared concerning landforms, climate, and vegetation. The homogeneous features of the Moldavian Tableland are presented as arguments to be part of Romania in its entirety. Therefore, the Prut should not divide this uniformity with a state border along it (e.g. the brotherhood of the woods and the sisterhood of the vineyards):

"For the Prut, there is nothing that shows such a change. On both its sides there is one and the same area as landform, climate, and vegetation. The Moldavian Tableland, with its wavy blunt hills, is the same from the Siret Valley to the Dniester. The climate, with the same winds and with the same weather rich in rainfall comprises again the entire area to the Dniester. The same vegetation ignores the Prut completely. The oak and beech forests, when man had not cut them down, had formed the famous brother woods again to the Dniester. The vineyards of Jassy and Cotnari found their sisters on the hills of Kishinev" (Gheorghiu \& Simionescu, 1935, p. 15, my translation).

Another fact enforcing the above argumentation is that the other side of the Dniester pertains to "another world":

"Standing on the bank of the Dniester one can easily realise that beyond it there is another world. The hills become lower in height, up to the horizon, where the smooth-faced Russian platform spreads. Also the climate and vegetation of the eastern lands undergo a change. The strong frost does not allow the beech to grow, and the grape vine disappears completely. Instead of the forests, the short grass steppe unfolds uninterrupted. Only in the southernmost parts this steppe stings like a pike in the land of Moldavia and from here in that of Wallachia, and later this allowed the migratory people from the steppe to find here, in our country, a favourable place to live. So, these 
are the proofs that show us that the Dniester is the true geographical border" (Gheorghiu \& Simionescu, 1935, p. 15, my translation).

The third criterion is called the ethnographicone. According to this criterion, the border should be placed where the distribution of a certain people ends:

"c) A border should be there where there is a stop to the spreading in mass of one and the same people (ethnographic border)" (Gheorghiu \& Simionescu, 1935, p. 15, my translation).

The term people (i.e. "neam" in Romanian) is introduced and defined based on the same blood of the people and on the same faith. And also based on customs, language and history (historical past):

"The riverbed of the Prut was crossed by one and the same people for centuries. The Moldavians beyond the Prut, blood brothers and having the same faith as the ones here stood high on the Romanian land down to the Dniester. Even though the old Romanians crossed the Dniester, we should still consider it an ethnographical border because it separates two distinct peoples. The Romanians from the (Ukrainian) Slavs, distinct as origin, customs, faith, language and history" (Gheorghiu \& Simionescu, 1935, p. 15, my translation).

The last criterion is the historical right over the territory. This is exemplified through the case study of historical Moldova, which lies between the Siret and the Dniester. The institutionalisation of half of Moldavia, between the Prut and the Dniester, as a differentregion, is underlined: it was given the name of Bessarabia (i.e. Basarabia in Romanian) by its former rulers (i.e. The Russian Empire) "in order to portray it as a distinct country" (Gheorghiu \& Simionescu, 1935, p. 16). A golden period in the history of Moldavia is remembered, that of Stephen the Great, in order to support the unity of the territory between the Siret and the Dniester:

"d) Besides all this, we can add, as the last strong argument, our historical rights on the Moldavia between the Prut and the Dniester, called much more later by its rulers with the name of Bessarabia, in order to portray it as a distinct country.

Let us remember that before Stephen the Great and much after his reign (1812), who said Moldavia could not stop to the Prut, but to the Dniester, along its banks being situated the border defence fortresses" (Gheorghiu \& Simionescu, 1935, p. 16, my translation).

If established on the Prut, the eastern border is presented as a key dividing line between two contrasting natural landscapes and cultures.

After the example about right and wrong borders, in the case of the Eastern border of Romania, the textbook insists with plenty of details on describing the borders of Romania and the reasoning behind their creation as they are. Due to the focus on this theme of borders and of the bordering process, one realises that this is a hot topic when discussing the Romanian nation and its territorial identity. For example, authors underline the arbitrariness of the western border and the fact that the historical rights of the Romanians against the Hungarians were not considered during the Peace Treaty (Gheorghiu \& Simionescu, 1935, pp. 18-19) and then devote several pages and a series of scientific arguments to constructing the image of the "appropriate" eastern border.

The northern border to Poland and Czechoslovakia is mostly a natural one (made up of mountains and rivers) and partly featuring conventional lines (Gheorghiu \& Simionescu, 1935, p. 17). The authors explain that more than half of the Maramureş belongs to Czechoslovakia because the principle of the nationalities required that it was no longer part of Romania (Ukrainians and Jews changed the Romanian character of the region, although they arrived later 
in that area) (Gheorghiu \& Simionescu, 1935, p. 17). Immigration is seen as a security matter, affecting state borders, and defining the nation-state.

These borderlines are based on a selection of natural elements (i.e. natural landscape according to this textbook) and cultural features that were emphasised as characteristic to the Romanian nation (Table 1). The borders established through the Peace Treaty of Trianon (1920) are presented and then the reasons for establishing them are discussed in terms of fairness or lack of it, of easiness to defend in case of war or not.

Table 1. On the borders and the neighbours of Romania

\begin{abstract}
"Romania almost reached its natural borders, comprising most of the Romanian people. In the boiling seether of Europe, the borders, through which we ensure the territorial and political integrity of a country, have been changed numberless times and marked off without considering the human element which forms the specificity of the national states.
\end{abstract}

As a result of the most recent transformations brought about by the World War (1914-1918), starting from the principle of nationalities, Romania only partly reached its original borders. The historical and geographical borders of the old Dacia - the Tisza - the Dniester - the Danube and the Sea corresponding to the true ethnic limits of the Romanian people, could not be achieved entirely. The millennial Hungarian rule over Transylvania and over areas neighbouring the tableland, spreading to the riverbed of the Tisza, smashing, and leaving in inferiority the autochthonous Romanian element, through denationalising and late mixing of polyglot Hungarian, German, and Serbian populations, spread especially through the peripheral areas, provided us to the west with an artificially marked border, across a lowland.

Considering the borders that still have the mission to ensure the first defence lines during war, Romania is better off than many European countries. Measuring from the west to the east $800 \mathrm{~km}$ and from south to north $600 \mathrm{~km}$, it is close to the round form of a slightly flat circle. This regular form provides Romania with shorter borders. Their total length is of almost $3,700 \mathrm{~km}$, with only $1 \mathrm{~km}$ to $100 \mathrm{~km}^{2}$. Besides this, Romania is better off than its neighbours also considering the nature of its borders. Three quarters $(2,880 \mathrm{~km})$ are natural borders, made of mountains, the Sea, and rivers, and only a quarter $(820 \mathrm{~km})$ are conventional.

The eastern border is entirely natural, its first part being formed by the Black Sea and then by the Dniester.

The shore of the Black Sea forms the south-eastern border, on $450 \mathrm{~km}$ from Ecrene to the lake through which the Dniester leads its waters to the Sea. To this part, we benefit from the wide-open window to the 'Big Sea', because the Black Sea represents the free path to the Orient and the Occident.

The lake of the Dniester and then the river valley to its confluence with the Zbruč river, to the west of Hotin, is the border with Ukraine $(800 \mathrm{~km})$. Its riverbed, deeply dug into the hard cliff and having a large meadow (10-20 km) in its lower part, forms a steady border, dividing two distinct geographical regions. They say that Asia begins at the Dniester" (Gheorghiu \& Simionescu, 1935, pp. 13-15, my translation).

"For more than 100 years, by mangling Moldova into two parts, we had the Prut as a border. That the Dniester is the border of our country and the Prut 'cursed river' was only an unenduring proof of unjustness, without being a true border, there is no doubt in anyone's soul who was taught to think right and who has no hidden thoughts" (Gheorghiu \& Simionescu, 1935, p. 15, my translation).

"The northern border in its entirety, being mostly a natural border, defends quite well our country in this part. 
The western border, separating us from Hungary and Yugoslavia, should find its native border in the winding route of the Tisza, blood brother with the Dniester. The Hungarians' too long rule over the areas beyond the mountains and strive to denationalise the Romanians made it possible for new foreign settlements to be created on this other side of the Tisza. What happened to Maramureş also happened to Crişana and Timişana.

Towards Hungary, our first neighbour to the west, the border starting from Halmeu is formed by a conventional line that cuts the Tisza Plain from north-east to south-west. It is traced to the west of Satul Mare, Carei $(10 \mathrm{~km})$, Oradea and Salonta and descends to the Mureş Valley at Nădlac, to the west of Arad. It goes on a small distance on the Mureş, up to Maca, left to Hungary, from where it descends beneath the Mureş, to the west to Beba-Veche, where it meets the border to Yugoslavia.

Towards Yugoslavia, the second western neighbour, the border, leaving the Tisza, as it does towards Hungary, is made also of a conventional line heading south-east. Leaving aside a considerable area of the rich field of the Banatian Torontal, the border passes nearby Jimbolia, Partoş, to the east of Vârşeţ and Biserica Albă (completely Romanian) and reaches the inferior valley of the Nera river. It follows the valley of this river closely to its inflow and ends at the Danube, $(4 \mathrm{~km})$ west of Baziaş.

Except for the small parts of the Mureş and the Nera, the western border is entirely conventional. In this whole part, our inherited land suffered the most painful amputation, because beyond the present border there are many Romanians and villages that are completely Romanian and that must further cope with foreign rule, inimical to them" (Gheorghiu \& Simionescu, 1935, p. 18, my translation).

"Towards Yugoslavia the unjustness was greater, because if the Hungarians can justify the border through their presence on the other side of the Tisza, the Serbians cannot. This people never went to the north of the Danube. Only occasional packs of erratic fugitives searched for Hungarian protection in the eastern parts of the Banat, one of the oldest and strongest fortresses of Romanianness. But appetite comes with eating! If, at the beginning, the Serbians asked only for one small patch of land behind Belgrade, when the final borderline was established, the Romanians had no defender of their interests and justness, and our neighbours gained, to our loss, an unjust border, non-geographical and without any ethnographical value.

The southern border lying on the Danube is natural on its longest part. From Baziaş to the mouth of the Timok (for $250 \mathrm{~km}$ ), the Danube separates us from Yugoslavia, and from here to Turcşmil (for $418 \mathrm{~km}$ ), it separates us from Bulgaria. Towards this neighbour, the border is a conventional line that descends from Turcşmil towards the south-east across Deliorman and exits at the shore of the Sea, at Ecrene (219 km)" (Gheorghiu \& Simionescu, 1935, p. 19, my translation).

However, the conclusion is that Romania has almost a round shape and therefore finds itself in a privileged position in comparison to other European countries. Thus, borders are represented also as a matter of security in a hostile environment:

"Looking at the borders, thinking also of other European countries, we have the right to say that Romania is better individualised than many others. Having shorter borders, due to its almost round form, thus being easier to defend and these borders, for most of their length, being natural, we can say that Romania almost reached its original borders" (Gheorghiu \& Simionescu, 1935, p. 19, my translation).

The metaphor of the isle is used to portray Romania in the map reproduced below (Figure 13). Slavs and Mongols surround Romania, separating it from the other Neo-Latin peoples (Gheorghiu \& Simionescu, 1935, p. 20). 


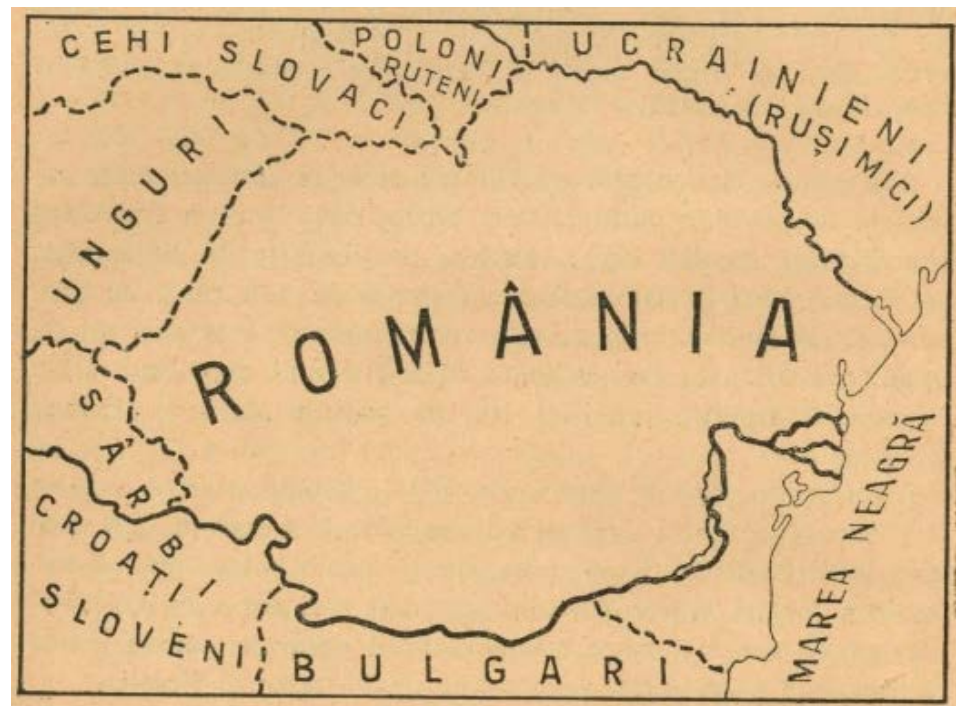

Figure 13: "Romanians like an astray island from the other

Neo-Latin people, being

surrounded by Slavs and

Mongols"

Source: original title in Gheorghiu \& Simionescu, 1935, p. 20

Then, the metaphor of the sun is employed, where the Romanian people is the centre and the rays are the Romanians living abroad. Romania resembles a sun: a compact area between the Danube, the Dniester, and the Tisza, with rays outside this area, among other peoples:

"Around the borders as a circle, almost full of the Romanian people, there are other six different peoples. Contact with them is not limited to the borders. Almost everywhere there are Romanians left beyond the present borders. If we imagine our country as the disc of the sun, from all around Romanians spread as the sun rays. These are the Romanians beyond the Dniester, in Czechoslovakia, in Hungary, in Yugoslavia, and in Bulgaria" (Gheorghiu \& Simionescu, 1935, p. 22, my translation).

Another metaphor closely following the previous one is that of the Romanians from abroad - an army guarding the homeland. These Romanians living abroad form the country's "ethnic guard":

"Our people overflow the enlarged borders, forming an ethnic guard around our country" (Gheorghiu \& Simionescu, 1935, p. 22, my translation).

Reciprocal help between the ones within and outside the country's borders is seen as a solution to strengthen the national feeling:

"It is high time that we help these brothers of ours from foreign countries in any way we can, in order to increase their awareness about their people; only thus we can help each other" (Gheorghiu \& Simionescu, 1935, p. 22, my translation).

Then the metaphor of the island is visited again (Gheorghiu \& Simionescu, 1935, p. 22), this time not to show the cultural and ethnic differences between Romania and its neighbours, but to show the danger of being an island in a sea, a sea whose waves hit systematically at the basis of this island trying to destroy it:

"We need to strengthen our souls. The peoples around us do not have the same origin like us. At the mouths of the Danube, the Romanians appear as an isle in the open sea. The stormy waves hit its basis from all parts, trying to destroy it. If this island is made of soft stone, with cracks in it, the waves enter even through the smallest one and make it collapse slowly, but surely (Gheorghiu \& Simionescu, 1935, p. 22, my translation). 
This idea becomes even more menacing when authors plainly state that Hungary will never be a friend of Romania because of its territorial loss (Western Romania and Transylvania) to the latter. Hungary is presented as a hereditary and everlasting enemy - therefore, the border towards Hungary will always be a contested one:

"Nobody should forget that Hungary can never be our friend. It does not forgive the loss of the territory it ruled, with no right, for more than one thousand years" (Gheorghiu \& Simionescu, 1935, p. 23, my translation).

In addition to this Hungarian menace, the Slavs who surround Romania are another danger. Thus, the island metaphor portrays the Romanians' ethnic isolation:

\begin{abstract}
"Again, we should not overlook the fact that blood never becomes water. Except for Hungary, all the peoples surrounding us are of Slav origin. Now they are divided into states that fight with each other, as it is the case with Serbia and Bulgaria. But at great celebrations, they never lose the opportunity to remember that they have the same origin, as Slavs. Nobody knows what the future can bring" (Gheorghiu \& Simionescu, 1935, p. 23, my translation).
\end{abstract}

In this process of bordering, two other imagological mechanisms developed: that of stereotyping and of Othering. Spatial imageries are created where the Other is an enemy, a threat to the borders of the nation, wanting to take parts of the nation-state. Thus, a geography of exclusion is written, where all neighbours are a threat to the life of Romania and Romanians and this discourse is part of the overarching one, of establishing, legitimising, and preserving Greater Romania's borders. However, this regressive goal of Othering and implicitly excluding the internal and external ethnicities serves the process of creating a stable nation-state and the stability of borders is one key element testifying this. Secondly, this process of Othering was realised with the declared aim of ensuring Romanians' social cohesion, their ethnic solidarity (e.g. the metaphor with the island and the menacing waves of the sea).

The past is invoked as an argument to support the thesis of imminent danger at the borders of Romania and also to compel the present inhabitants to defend their heritage:

"The past acknowledged by history may be a guarantee for all our present neighbours that we have never started any unjustness. The dangers were and are big and many. Our ancestors' stormy past is the living proof. Let us never forget this past and strive to keep untainted our sacred heritage, full of blood sacrifices" (Gheorghiu \& Simionescu, 1935, p. 23, my translation).

Romanians' defence weapons are their work and culture in order to increase the solidarity necessary for coping with the ethnic Other, whether outside or inside the country ( $c f$. also Caramelea, 2015, pp. 168-172). The idea of the Romanian culture bounded between the nationstate borders is promoted, ignoring the fact that "'culture' is always based on social interaction, circulation and loans" (Paasi, 2019, p. 16):

"In our ethnic isolation, it is necessary to feel solidarity with one another, a soul strengthening itself for collective unity and raising the awareness about the duty that each of us has for the country in order to defend and develop it through individual work and culture" (Gheorghiu \& Simionescu, 1935, p. 23, my translation).

The discourse on borders refers not only to the external ones, separating Romania from neighbouring countries, but also to the internal ones (e.g. between the urban and the rural areas - cf. also Caramelea, 2015, pp. 162-165), which are not the focus of this study (cf. Figure 14). However, it is worth mentioning that the Othering of the neighbours was true also for the ethnicities living in Romania alongside Romanians (cf. Caramelea, 2015, pp. 162-165). For instance, authors argue the presence of foreigners (i.e. Ruthenians, Jews) led to losing half of Maramureş, according to the principle of nationality, when Greater Romania was created. 
Romania was a rural country, with $82 \%$ of its inhabitants in the rural area (Figure 14), with $73.1 \%$ Romanians, followed by Hungarians, Jews, Germans/Saxons, Bulgarians, and Russians (in the decreasing order of their percentage out of Romania's total population) (see title of Figure 15; Gheorghiu \& Simionescu, 1935, p. 160). Other nationalities include ethnicities present on the Romanian territory (Figure 15). This time, the island metaphor is used to portray various ethnics within Romania. These are called "foreign elements," while the Romanians form a "compact mass" (Figure 16).

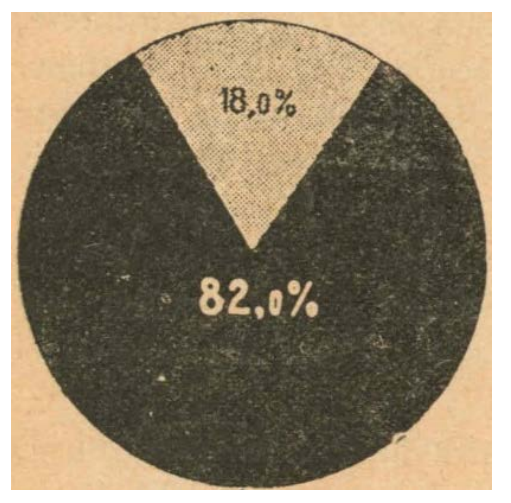

Figure 14: "The population of the villages in comparison to that of the towns. The 1930 census (after dr. G. Banu)"

Source: original title in Gheorghiu \& Simionescu, 1935, p. 160

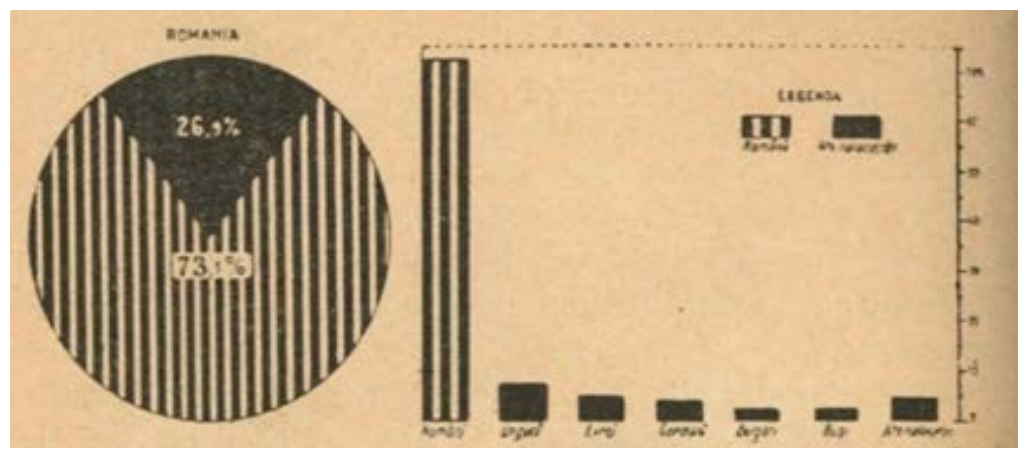

Figure 15: "The Romanian element compared to the other nationalities (after Dr. G. Banu)"

Source: original title in Gheorghiu \& Simionescu, 1935, p. $160^{1}$

Natural borders and fair conventional ones were displayed as a normative prerequisite of a legitimate nation-state. The authors not only put great emphasis on natural borders, but even seem to be fascinated by them (Caramelea, 2015, p. 158). Thus, Greater Romania seems to be characterised by a predestined territory, where people of the same ethnic origin and culture perfectly overlap the territory bordered by natural elements; thus, the harmony and the homogeneity of the nation-state becomes obvious. Internal homogeneity and the othering of neighbours of different ethnic origin and culture is accompanied by the foregrounding of the exceptional features of natural borders ( $c f$. also Caramelea, 2015, p. 158). Physical determinism transpires through the authors' argumentation when explaining the exceptional harmony between Romaniansand their territory. Moreover, the soul of the people reflects the uniformity of the physical environment (Figures 15 and 16):

"The ethnic and political unity of the Romanian people. Romania, in comparison to other countries, has a big advantage. Its land, so harmoniously built up, as relief and waters, is inhabited everywhere by a single dominating people, with eminent features, the same from one end to the

${ }^{1}$ In $1912,82 \%$ of the population of Romania lived in the rural area (Hitchins, 1994, p. 164). 
other of the country. It is the native people, developed in harmony to these places, thus adapted to its living environment. Everywhere, one can hear the same language; they have the same faith; the people keep the same customs no matter where they live, even beyond the Dniester. The soul of the people is uniform, similar to the physical unity where they live" (Gheorghiu \& Simionescu, 1935 , p. 161, my translation).

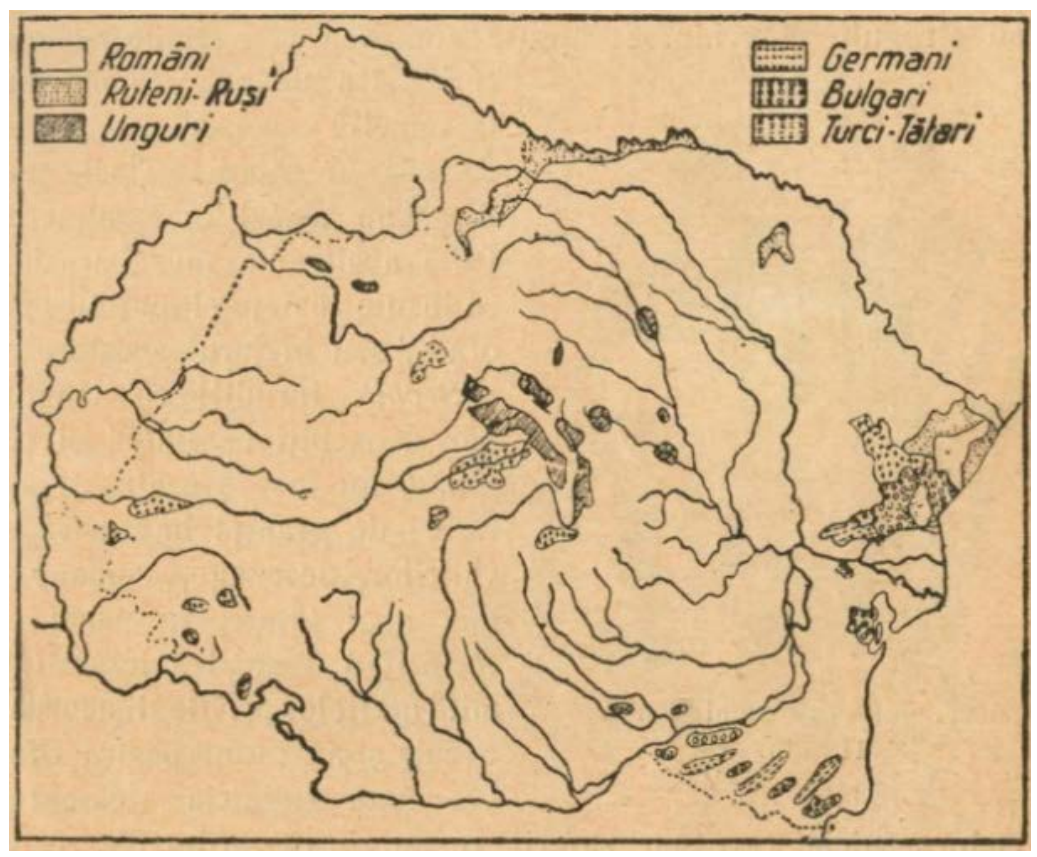

Figure 16: “Ethnographic Romania. The Romanians form a compact and unitary mass; the other foreign elements appear only as scattered isles"; The legend: Romanians; Rhutenians-Russians; Hungarians; Germans; Bulgarians; Turks-Tartars

Source: original title in Gheorghiu \& Simionescu, 1935, p. 161

One can identify a continuity in the way borders are represented(see Figures 5 and 16 ) in these textbooks from before and after the Great Union. These textbooks were officially approved by the Ministry of Education and thus their discourse was considered a legitimate one.

Wallachia and Moldavia united in 1859 and then Dobrudjajoined them as a result of the Treaty of Berlin (1878), after the Russian-Turkish war of 1877-1878 (Gheorghiu \& Simionescu, 1935, p. 157). As a consequence of the Great War, through the Peace Treaty of Versailles (1919), Romania gained Transylvania and Bessarabia (Figure 17). 


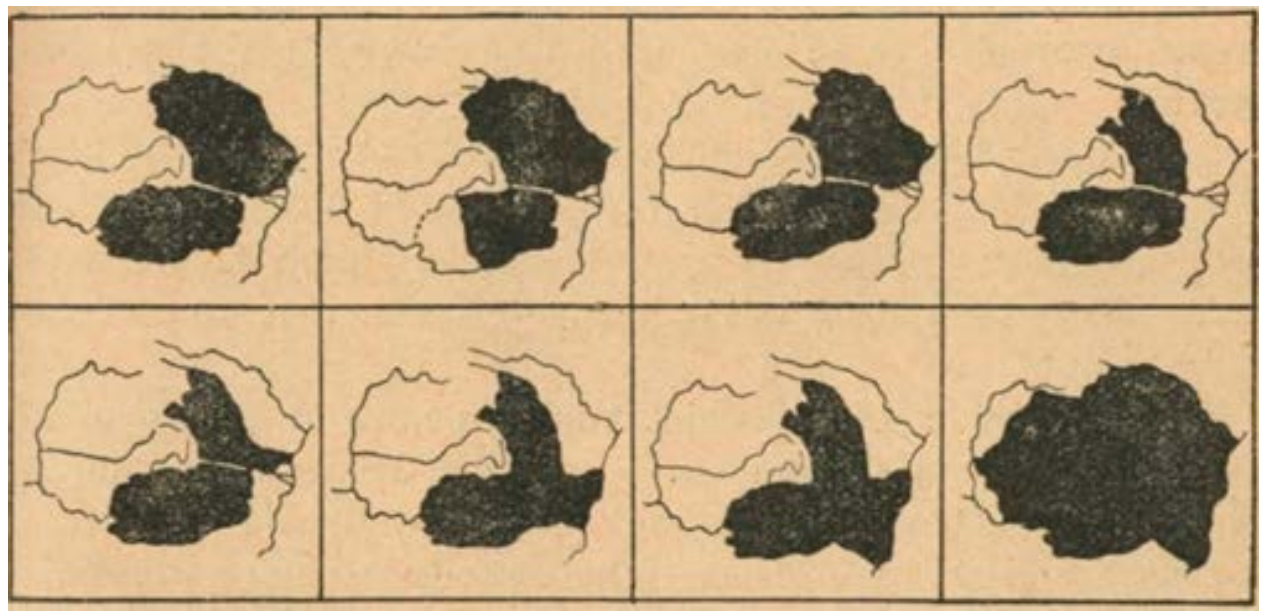

Figure 17: "The territorial changes of Romania from the $18^{\text {th }}$ century to present; $1-1700 ; 2$ 1718; 3 -1775; 4 - 1812; 5-1856; 6-1877; 7-1913; 8-1919 (after Dicţionar Enciclopedic)" Source: original title in Gheorghiu \& Simionescu, 1935, p. 191

Concerning the Romanians beyond the country's borders, we find out that "completing the Romanian land could not bring together all Romanians. Many of our brothers are still spread in all four directions outside our country's borders" (Gheorghiu \& Simionescu, 1935, p. 197, my translation) (Figures 18 and 19).
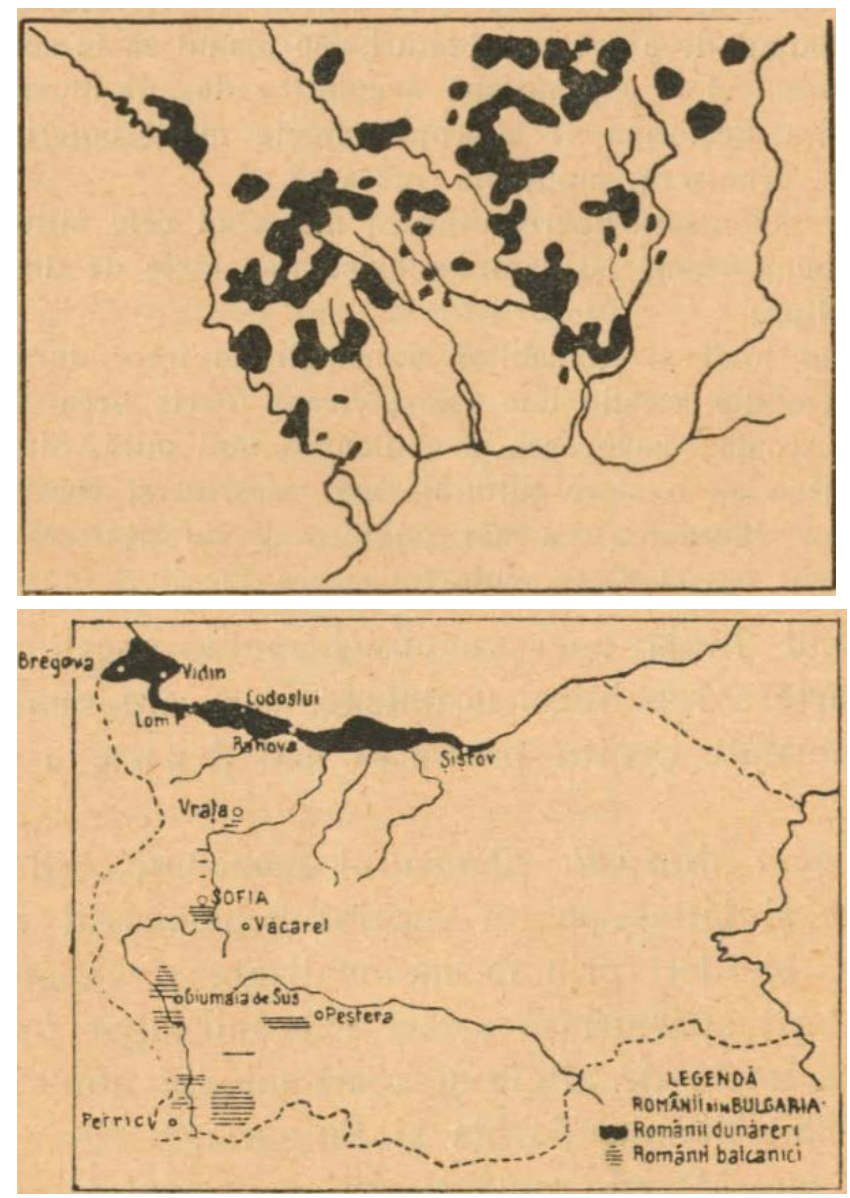

Figure 18: "Romanians beyond the Dniester"

Source: original title in Gheorghiu \& Simionescu, 1935, p. 197

Figure 19: "Romanians in Bulgaria. Legend: The Danubian Romanians; The Balkan Romanians"

Source: original title in Gheorghiu \& Simionescu, 1935, p. 200 
Further on, authors show that Romania's political unity reflects the homogeneousness of the natural environment, thus naturalising the nation (cf. Kaufmann \& Zimmer, 1998) (Figures 20 and 21).
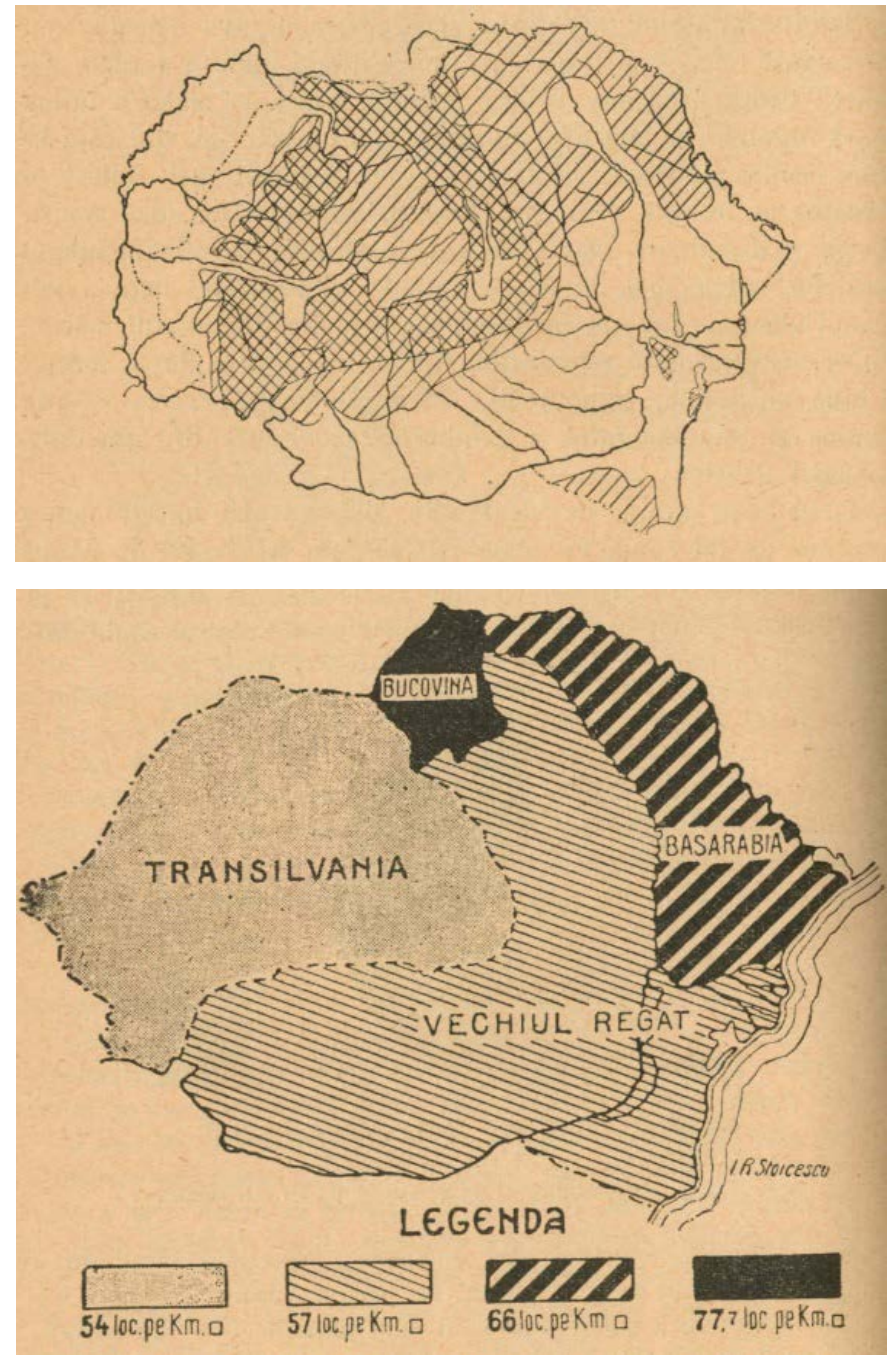

Figure 20: "Blending together the three landforms. - Crossed lines = mountains; inclined lines = hills; white $=$ fields"

Source: original title in Gheorghiu \& Simionescu, 1935, p. 100

Figure 21: "Density of population after the 1930 census (after Dr. G. Banu)"

Source: original title in Gheorghiu \& Simionescu, 1935, p. 158

Geographical Education as a Soft Bordering Practice: The Romanian Landscape and the Romanian Nation

In the first half of the $20^{\text {th }}$ century, the wished-for or newly-established and contested borders of Romania generated a lengthy and argumentative discourse about state borders and about the history and geography of the territories inhabited by Romanians. Ethnocultural identity concepts and conceptions of national identity were provided for the young and not only. Geography of Romania school textbooks were not apolitical, but reinforced a socio-spatial consciousness, based on the natural and anthropic features of the borders and on how they were represented, revealing the social practice of the educational discourse about border areas.

National identity was the constant concern of the period (cf. also Caramelea, 2015, p. 157) and this was reflected in representations of the borders in school textbooks on the Geography of Romania. These representations are dominated by the iconic figure of the map, the stereotype 
of the map as the easiest way to represent space, although, in time, maps gain autonomy, they become actors.

The contexts of writing and publishing the images in the analysed textbooks were different, but similar in what the justifying of the borders was concerned. The aim of these representations was a progressive one: to form the Romanian nation, especially in the case of the first textbook, authored by Murgoci and Popa-Burcă $(1902,1905,1910,1916)$. "The national question" is the political project of making Greater Romania, that is uniting all territories inhabited by Romanians into a single state (Caramelea, 2015, p. 157). In the second case (Gheorghiu \& Simionescu, 1935), the aim of these representations was still progressive: to justify the existing borders and maintain the nation during a historical period that was unstable both nationally and internationally.

To sum up, geographical education reflects the stages of the process of institutionalizing the Romanian state:

“(1) territorial shaping (implies borders, often taken for granted in geography and IR), (2) symbolic shaping (naming, symbolism, narratives, identity discourses, memory, past), (3) institutional shape (politics, economy, culture, stabilizing institutions like education) and (4) establishment" (Paasi, 2019, p. 20).

During these stages, the feelings and expectations of the inhabitants are shaped and then reproduced through social practices and discourses (of various institutions and the school was one of them). The nation state of Romania is conceived of (and this is a stage presented in the textbook of 1916) and then its existence is testified and justified (through the discussion of the borders in the geography school textbook of 1935).

The bordering processes are contested ones or likely to be contested, therefore generating the ample discussion about them in these school textbooks of geography. Representations are diverse: imagistic (including maps), linguistic and models. The same data can be represented in different ways and thus meaning is further created through representations. This is valid also for the two analysed textbooks. Collective meanings are created and communicated through these representations (visual and linguistic) about the borders. Greater Romania, as the ideal form of the Romanian national state (Mârza, 2015, p. 1035), defined the specificity of the historical discourse during that period. The manner in which these textbooks reflect the political union, and the border changes is similar to a historical process that leads to the creation of the national state (i.e. Greater Romania). These textbooks may be read as geopolitical discourses:

"The 'truth' that geopolitical texts have provided eventually is historically and spatially contingent and this holds particularly good in the case of knowledge that has to do with society and people" (Hajdú \& Paasi, 1995, p. 35).

Related to education through images, all images of borders in the two Geography of Romania school textbooks (the first one with four editions analysed here), were tools in educating people's representations of their country's ("patria") borders. I argue that the discourses based on imagery were part of a network of representations or a coherent cultural discourse about the Romanian nation, "the idealized sociopolitical alchemy of our time - the nation-state" (Silova, Yaqub \& Palandjian, 2014, p. 103) pervading past and present representations about Romania's borders, about who the Romanians were. These visual discourses on borders and the related explanatory text constructed a "collective socio-spatial consciousness" (Silova, Yaqub \& Palandjian, 2014, p. 103), through two processes: "socializing allegiance to particular spatial units, and, recursively, imbuing space itself with social and cultural character" (Silova, Yaqub, \& 
Palandjian, 2014, p. 104, according to Duchacek, 1970; Newman \& Paasi, 1998). Physical, cultural, social, and political meanings were attached to borders.

The historical construction of this socio-spatial consciousness (Paasi, 1999, p. 22) is reflected by the discourse on the state borders of Romania; that is why, by reading the school Geography textbook, the young get plenty of information about the history of the territories inhabited by Romanians. In this process, spatial socialisation is paramount:

"spatial socialization [is] the process in which individual actors and collectivities are socialized as members of territorially bounded spatial entities through which they internalize collective identities and adopt shared traditions, memories and other elements of spatial imaginaries" (Paasi, 2019, p. 15).

The text, either written (explaining the images, titles, and figures, etc.) or visual, presents conceptual anchors (Silova, Yaqub \& Palandjian, 2014, p. 107) about the national space of Romania. One of these conceptual anchors of space representations are those of boundaries/borders of Romania and Romanianness, which help to understand the Romanian national space in the social, cultural and political fields. The definition of the nation-state as a construct with multiple facets has already been discussed in relation to geographical textbooks:

"In the contemporary world, the nation-state continues to be the dominant socially, culturally, and politically constructed territorial frame from which people anchor and derive their identityperhaps the most prominent creation of modernity that (still) cannot be 'escaped'." (Paasi, 1996a, p. 39, quoted in Silova, Yaqub \& Palandjian, 2014, p. 105).

The symbolic landscape of the borders is built discoursively through listing the key features of the established or contested borders. In presenting and discussing these features, the authors partly create the iconography of nationhood (e.g. natural and cultural landscapes, symbols, legends, myths) and emphasise people's imagined relationship with nature, and the powerful symbolic links to Romanians' territorial identity.

Previous studies on Geography textbooks underlined the long-lasting impact of the representations circulated in the school system:

"Imbuing the border territories with identities and vice versa, landscapes document human history by capturing the significance of geographical space in the collective memory of people" (Silova, Yaqub \& Palandjian, 2014, p. 107).

Such educational discourses reflect the socially embedded networks of power, the discursive practices, and the hegemonic narratives (Silova, Yaqub \& Palandjian, 2014, p. 109). In addition, I consider that geographical education, through school textbooks, tends "to make space incontestable inasmuch as they provide an authoritative 'reading' of social norms, values, and symbols attached to it" (Silova, Yaqub, \& Palandjian, 2014, p. 104).

The geographical discourse aims to naturalise the political borders of Romania by providing students with knowledge about the true or "authentic" borders of their country. Borders are not just cartographic conventions, but they are invested with feelings and are scientifically justified or assessed. The authors present students with what should be the model borders and then reality is merged with it, the landscape is geographically and historically decoded, and the young Romanians are taught how to look at the borders and assess their value. This pedagogy of space creates geographies and imaginations about Romania. The textbooks combine written word, maps, and graphs to characterise the "Romanian element" and Romania as a bordered space.

The discourse on the borders of Romania is also constructed as a political critique, considering the reasons and the context that led to the respective borders, close to or far from the ethnic, 
historical, and cultural realities on the ground. Maps are referential when representing and discussing borders. However, the written text about them is rich in arguments and details. According to these, authors underline that peoples and territories can be divided appropriately when cultural boundaries are considered. Besides the cultural features, geographical ones enable the naturalisation of the appropriate borders. The geographical pedagogy of space thus acts as a strategy in further naturalising the authentic borders or in contesting the unjust ones and therefore rehearsing this discourse starting with school textbooks. The textbooks argue in favour of the need to return to the justness of the old borders of Dacia in order to be true to the past and to a space that renders the essence of Romanianness.

Maps are imbued with meanings of power and control over space, they are visual ideological discourses, but, at the same time, they represent scientific "objectivity" and "truth". Grounding their discourse about the features of borders on scientific objectivity, authors claim the universality of their arguments and the impossibility of being contested because of this. They thus institutionalise through school and geographical education the hegemonic discourse about the state borders of Romania. As such, the analysed discourse on the Romanian borders is part of the nation-building process, of the formation of the Romanians' socio-spatial consciousness, and reflects the changing geopolitical landscape before and after World War I.

For instance, the textbook of 1935 and its discourse on borders embodies a scientific gaze upon the borders of Romania, that is characterised by the rationality of science, but, at the same time, serves the nationalist discourse. Even earlier, other authors openly adhered to the nationalist discourse, as in the case of the 1916 edition of the first textbook. These authors argue that they explore the link between a just or appropriate reality and the (fair or unjust) borders by conveying their representations through images (maps, graphs) and word text, all of which are cultural texts constructing Romania, and, at the same time, questioning its borders based on historical and geographical reasons.

The maps of Romania are used by the authors of these two textbooks as tools in their argumentation, enabling a nationalistic and motivating discourse. From the authors themselves, we see that maps do not incarnate the truth in all border-related situations and discourses about Romania, but sometimes they can produce landscapes lacking any historical, ethnic, or cultural ethics for the Romanian state (cf. the discussion about the western border, with Serbia, in the 1935 textbook). The geopolitical heritage is reflected in the maps of Romania, referring to unjust political decisions through conventional borderlines, as the authors argue. These textbooks naturalise political borders, where accepted, as the appropriate ones and reflect an essentialist approach to the nation and its borders (i.e. they are both century-long ideals or dreams; they are not considered to be constructed). The landscape is part of the process of naturalising the body of the nation through its borders. According to the textbook, the old borderlines of Dacia should be the basis of the "ethnical cartography" (Fall, 2006, p. 666) of the Romanian nation.

Authors refer to the "natural" rootedness of the borders, arguing "their adherence to natural features, rivers, mountains, topography" (Fall, 2006, p. 665), which the authors consider to be better and not as arbitrary as the political ones. It seems that natural borders are the best and unquestionable, comprising the body of the nation. The landscape is presented as uncontroversial in the process of establishing these natural borders. The materiality of the natural or physical border seems to be favouring objectivity, as nature seems to have predetermined the limits of the Romanian state. The harmony of the landforms should be included within the normal/native borders of the country, whose body should no longer be crippled by any geopolitical processes, by foreign and inimical interests. 
The physical features of Romania are turned into a source of collective identification, especially during critical moments in history. The Prut and the Dniester are symbols of the incorrect and correct state borders. For instance, the Prut is called out for not appropriately dividing natural landscapes and cultures or national features. It does not offer the purity and stability required from state borders. The Dniester is nationalised in this educational discourse. The Dniester is singled out in the eastern border discourse due to its national significance for the unity and territorial identity of Romania. It is being considered a symbol of stability, justness, and historical past. Similarly, the Romanian nation is also naturalised through the bordering discourse, being given a unified and homogenous appearance. The natural borders make Greater Romania authentic. The Romanian borders reflect the national reconstruction project where national identity relies on authenticity: the ethno-historical past and its naturalisation (cf. Kaufmann \& Zimmer, 1998, p. 3, for a discussion about the naturalisation of the nation). Nature is politicised. We see how nature is assessed based on the political and historical context of the respective period and it is used to justify, legitimise, and delegitimise the Romanian state borders.

Landscape symbolism serves the geographical discourse which creates national authenticity using the borders of the Romanian state and nation. The territory of Romania is depicted as a reflection of the Romanians' features: homogenous, unified, ancient, long-lasting, resilient, living in a symbiosis with the people, pure, simple, fighting for and loving freedom. The natural landscape is nationalised, and the young generation's national consciousness is thus shaped, given that "it is surely true that "What men see in Nature is a result of what they have been taught to see'." (Hope-Nicolson, 1959, p. 3, quoted in Kaufmann \& Zimmer, 1998, p. 7).

The Romanian landscape makes the Romanian nation distinct, among other features. These textbooks are the product of nationalist geographers, the unity of natural and cultural traits (distinct ethno-historical past, ethno-linguistic characteristics) scoring high on their agenda. In these textbooks, we see the relevance of the national landscape for the educational and official narrative about the Romanian nation-state. Through its nationalisation, the natural environment becomes the homeland (Kaufmann \& Zimmer, 1998, p. 27), where the nation is defined "as a cultural order composed of certain values, symbols and ethno-historical myths" (Kaufmann \& Zimmer, 1998, p. 3).

These textbooks familiarise students with the official ideology of the Romanian political class, with "the assumptions it embodies about society, past, present and future" (Anderson, 1985):

\footnotetext{
"At its simplest, ideology refers to systems of ideas which give distorted and partial accounts of reality, with the objective, and often unintended, effect of serving the partial interests of a particular social group or class. Typically, they do so by appearing to represent the interests of all the various groups in society" (Anderson, 1985, p. 28).
}

The textbooks bring forth a classic discourse about original and natural boundaries, thus intrinsically including and advertising certain values, such as: truth, authenticity, justness, correctness, and legitimate knowledge.

Romanian students, however, through this discussion, become aware of the fact that borders and their representation on maps reflect power and their creators' interests. Thus, they could understand that representations (such as maps) are not impartial and that borders "do not hence embody any 'eternal truth of places' but rather are drawn on by diverging actors to sene particular purposes. Similarly, the spaces that borders enclose are never culturally 'pure'" (Paasi, 2012, p. 2304). Even though the Romanian borders reflect particular political interests at a certain moment, which is obvious from the discourse in these textbooks, authors argue in favour of scientific map-making, their arguments serving to legitimise Romania's interests or 
delegitimise those stands which are not considered acceptable. We can see that borders are useful for "container-based views on territory, region, and place" (Paasi, 2012, p. 2304). Therefore, the educational discourse in geography school textbooks is part of the official one, and it is itself a soft bordering practice enabling national socialisation and propaganda purposes. The geographical discourse is a part of the contemporary debates over politics, knowledge, and power and of their reflection in the reality of official borders.

\section{CONCLUSIONS}

Borders are historically contingent and depend for their creation and implementation on the discourses legitimising them. The focus of this article was on geopolitical representations and their role in the production of knowledge about the borders of Romania and about the Romanian nation in connection to the discourse on state borders. The published visual and textual representations of borders and of the features of Romania showcase a specific way of representing and then seeing and experiencing the Romanian space and society before World War I and during the interwar period.

The research material consisted of two Geography of Romania school textbooks. The political message they conveyed was especially straightforward when representing the borders of Romania. The state was enforcing its political powerand ideology through the discourse in the two analysed school textbooks. These were a media making the official discourse known to the students. The educational discourse in Geography school textbooks contributed to the process of institutionalising Romania as a state, with undisputable borders, where these were considered just. Its purpose was to enable people to identify themselves with either the desired borders (as in the edition of the 1902 textbook) or with the newly established ones (in 1918, and still discussed in the 1930s).

Teaching Geography and the nation's history was accomplished through the medium of Geography school textbooks. The researched visual imagery articulated Romanians' sociospatial consciousness of their country; it was part of the "pedagogy of space" (Newman \& Paasi, 1998) during the four decades from the beginning of the $20^{\text {th }}$ century. Power discourses and borders are strongly connected. The borders of Greater Romania were reified through the discourse of various institutions, and the school was one of them. The physical practices were easily translated into the educational discourse. Thus, borders were physically (or materially) and discoursively rooted. The discussion of the new state borders supported the creation of identity narratives for the Romanian state, for the territory of the nation, and for diverse ethnic groups, for the urban and rural areas ( $c f$. Caramelea, 2015). These identity narratives are meaningful in the context of legitimising discourses promoted by politics in the education system, mobilising people's imaginations, representations and ultimately justifying future actions related to creating the nation-state and guarding it against any external and internal dangers, as the authors of these textbooks argue themselves.

Geographical knowledge and especially representations of place, space and landscape are situated in the historical and political context of Greater Romania (before and after its creation), during the first half of the $20^{\text {th }}$ century, when a variety of images and especially maps were produced as part of the official discourse in Geography education. Understanding the historical context and presenting it briefly (both in this article and in the analysed textbooks) was useful in order to be able to deconstruct the meaning of the respective representations of borders. Pervading the geographical discourse, Romania's aim in World War II was to create Greater 
Romania again, but Romania lost the war and thus lost Bessarabia, Bukovina, and the south of Dobrudja (Quadrilateral), although it got back Transylvania (after signing the Peace Treaty of Paris, in 1947).

Representations of borders on maps and related text in school textbooks aimed at the spatial socialisation of Romanian students, and had a role in spatial imageries related to progressive goals (i.e. the nation, before 1918, and fortifying national consciousness after 1918, respectively), and partly regressive ones (excluding the Other, after 1918). When presenting the state borderlines of Romania, the authors highlight the historical, geographical, ethnic, and strategic relevance of these boundaries, while concomitantly employing scientific and patriotic arguments supporting these to engender place attachment and solidarity with the idea of the Romanian nation. The purpose of this discourse was a mainly progressive one - to form and then to preserve the nation -, working to create common representations for all Romanians who were enrolled in the education system and thus to integrate them in the larger imagined community of the nation. The official geographical educational discourse on state borders shows the institutionalisation of Romania as a state during the first half of the $20^{\text {th }}$ century.

Reflecting on the limitations of my research, I point out that I considered the construction of territorial identities through representations imposed from above and did not enquire about the process of its reception and transformation as a result of this interaction between the official discourse and people's thoughts and experiences of the respective realities. In the same vein as K. Verdery (1991), I limited my enquiry to the production process of culture (i.e. of spatial culture) and I did not also consider its reception.

Further research should focus on establishing the continuity of educational aims or lack of it in representations of borders and Romanian territorial identity, as reflected by those in Geography school textbooks, after 1948. Moreover, starting from the fact that "the spectrum of images is dependent on the historical period in which the text was written" (Bargal, 1994, p. 224), further studies should explore the extent to which these past representations also impact upon contemporary society and its values.

\section{REFERENCES}

AGNEW, J. (2008). Borders on the Mind: Re-framing Border Thinking. Ethics and Global Politics, 1, 175-191.

ANDERSON, B. (1983). Imagined Communities: Reflections on the Origin and Spread of Nationalism. London: Verso.

ANDERSON, B. (2019). Cultural Geography II: The Force of Representations. Progress in Human Geography, 43(6), $1120-1132$.

ANDERSON, J. (1985). Ideology in Geography: An Introduction. Antipode, 17(2-3), 28-34. DOI: 10.1111/j.14678330.1985.tb00330.x

AYRES, S. (2018). Regional Governance and Democracy. In Paasi, A., Harrison, J., Jones, M. (eds.), Handbook on the Geographies of Regions and Territories (pp. 219-230). Cheltenham, UK \& Northampton, MA, USA: Edward Elgar.

BABAlI, E. \& SHEIKHI, M. (2018). Traces of Neoliberalism in English Teaching Materials: A Critical Discourse Analysis. Critical Discourse Studies, 15(3), 247-264.

BAGOLY-SIMÓ, P. (2013). Still Red and in War or Just Poor? European Transformation Societies in Geography Textbooks. Journal of Geography, 112(3), 108-119. DOI: 10.1080/00221341.2012.693942

BANINI, T. (2019). Geografie culturali. Milano: FrancoAngeli.

BARGAL, Y. (1994). The Image of the Palestinian in Geography Textbooks in Israel. Journal of Geography, 93(5), 224-232. 
BOIA, L. (1998). Miturile comunismului românesc [Myths of Romanian Communism]. Bucureşti: Editura Nemira.

BOIA, L. (2011). Mit și istorie în conștiința românească [Myth and History in the Romanian Consciousness]. București: Humanitas.

BOTEA, B. (2013). Territoires en partage. Politiques du passé et expériences de cohabitation en Transylvanie. Paris: Editions Pétra.

CARAMELEA, R. (2015). A School Subject Serving the Nation. Geography Textbooks in Romania (1864-1945). History of Education \& Children's Literature, 10(1), 155-176.

CERULO, K.A. (1997). Identity Construction: New Issues, New Directions. Annual Review of Sociology, 23, 385-409.

CRAMPTON, J.W. (2001). Maps as social construction: Power, Communication and Visualization. Progress in Human Geography, 25(2), 235-252.

DE CILLIA, R., REISIGL, M., \& WODAK, R. (1999). The Discoursive Construction of National Identities. Discourse and Society, 10(2), 149-173.

DE SAUSSURE, F. (1986). Course in General Linguistics. Edited by Bally, C., Sechehaye, A., with the collaboration of Riedlinger, A. Translated and annotated by Harris, R. Chicago and La Salle: Open Court.

DODGE, M. \& PERKINS, C. (2015). Reflecting on J.B. Harley's Influence and what he missed in 'deconstructing the map'. Cartographica: The International Journal for Geographic Information and Geovisualization, 50(1), 37-40.

DUBOW, J. (2009). Representation. In Gregory, D., Johnston, R., Pratt, G., Watts, M.J., Whatmore, S. (eds.), The Dictionary of Human Geography, 5th Edition (pp. 645-646). Chichester: Wiley-Blackwell.

DULAMĂ, M.E. \&ILOVAN, O.-R. (2015). Development of the Geography School Curriculum in Romania, from the 18th Century to 1989. Transylvanian Review, 24(Supplement 1), 255-284.

ENTRIKIN, J.N. (2018). Geography of Experience: Place and Region. In Paasi, A., Harrison, J., Jones, M. (eds.), Handbook on the Geographies of Regions and Territories (pp. 44-56). Cheltenham, UK and Northampton, MA, USA: Edward Elgar.

FALL, J. J. (2006). Embodied geographies, naturalised boundaries, and uncritical geopolitics in La Frontière Invisible. Environment and Planning D: Society and Space, 24(5), 653-669. https://doi.org/10.1068/d3704

CILLIATOVA, O., LATUN, V., \& OKUNEVA, I. (2014). Visual Image of the Continent in Russian Textbooks on Geography (1825-2013). 4th World Conference on Learning, Teaching and Educational Leadership (WCLTA). Procedia Social and Behavioral Sciences, 141, 731-737.

FOUCAULT, M. (1971). L'Ordre du discours. Paris: Galimard.

FOUCAULT, M. (1986a). Space, Knowledge, and Power. In Rabinow, P. (ed.), The Foucault Reader. An Introduction to Foucault's Thought. London: Penguin.

FOUCAULT, M. (1986b). Truth and Power. In Rabinow, P. (ed.), The Foucault Reader. An Introduction to Foucault's Thought. London: Penguin.

FULBROOK, M. (2002). Historical Theory. Ways of Imagining the Past. London and New York: Routledge.

GERGEN, K.J. (2000). Social Construction and the Transformation of Identity Politics. In Holzman, L., Morss, J. (eds.), Postmodern Psychologies, Societal Practice and Political Life. New York: Routledge. Retrieved 22 November 2019, from https://www.swarthmore.edu/sites/default/files/assets/documents/kennethgergen/Social\%20Construction_and_the_Transformation.pdf

GHEORGHIU, N. \& SIMIONESCU, I. (1935). România. Pentru clasa a VIII-a, ediţia a II-a [Romania. For the 8th Grade, second edition]. Bucureşti: Editura "Cartea Românească".

GRUFFUDD, P. (1995). Remaking Wales: Nation-Building and the Geographical Imagination. 1925-50. Political Geography, 14(3), 219-239.

HAJDÚ, Z. \& PAASI, A. (1995). The Changing Image of Finland in Geographical Texts in Hungary: A Contextual Analysis. Fennia, 173, 33-51.

HALL, S. (1980). Encoding/decoding. In Centre for Contemporary Cultural Studies Culture, Media, Language: Working Papers in Cultural Studies (pp. 128-138). London: Hutchinson. 
HALL, S. (1997a). Introduction. In Hall, S. (ed.), Representation: Cultural Representations and Signifying Practices (pp. 1-12). London: Sage.

HALL, S. (1997b). The Work of Representation. In Hall, S. (ed.), Representation: Cultural Representations and Signifying Practices (pp. 13-74). London: Sage.

HARAWAY, D. (1988). Situated Knowledges: The Science Question in Feminism and the Privilege of Partial Perspective. Feminist Studies, 14(3), 575-599.

HITCHINS, K. (1994). România 1866-1947. Bucureşti: Humanitas.

HOOSON, D. (ed.) (1994). Geography and National Identity. Oxford: Blackwell.

HUGGINS, R. \& THOMPSON, P. (2018). Regional Innovation and Growth Theory: Behavioural and Institutional Approaches. In Paasi, A., Harrison, J., Jones, M. (eds.), Handbook on the Geographies of Regions and Territories (pp. 116-129). Cheltenham, UK and Northampton, MA, USA: Edward Elgar.

IANOŞ, N.-R. (2010). Educaţia în învăţământul primar românesc din Transilvania (1850-1870). Teză de doctorat [Romanian Primary Education in Transylvania (1850-1870). Ph.D. Thesis]. Universitatea "Babeş-Bolyai" ClujNapoca. Facultatea de Istorie şi Filosofie.

ILOVAN, O.-R. \& MERCIU F.-C. (2021). Building Visual Intertextuality and Territorial Identities for the Romanian Danubian Settlements during Socialism. Journal of Settlements and Spatial Planning, Special Issue 7, 15-50. DOI: $10.24193 /$ JSSPSI.2021.7.03

ILOVAN, O.-R. (2021). Visual Discourse on Territorial Development and Political Identities in Socialist Romania, in Comics for Pioneers. Finisterra, 56(116), 19-48. DOI: https://doi.org/10.18055/Finis21752

ILOVAN, O.-R., MAROȘI Z., ADOREAN, E.-C., URSU, C.-D., KOBULNICZKY, B., DULAMĂ M. E., COLCER, Al.-M. (2019), Learning and research by integrating the ICT and the theory of representations: mapping the industrial areas of Cluj-Napoca. Romanian Review of Geographical Education, 8(2), 58-77. DOI: 10.24193/RRGE220194

ILOVAN, O.-R. (2020). Discursul oficial despre identitatea teritorială a României în prezent [The Official Discourse about the Territorial Identity of Romania at Present]. Cluj-Napoca: Presa Universitară Clujeană.

ILOVAN, O.-R., BAGOLY-SIMÓ, P., \& HERBSTRITT, G. (2018). Visual Discourse in Romanian Geography Textbooks During Socialism (1948-1989). Romanian Review of Geographical Education, 7(2), 59-70.

JESSOP, B. (2018). The TPSN Schema: Moving beyond Territories and Regions. In Paasi, A., Harrison, J., Jones, M. (eds.), Handbook on the Geographies of Regions and Territories (pp. 89-101). Cheltenham, UK and Northampton, MA, USA: Edward Elgar.

JONES, R. (2018). Regions and Cultural Representation. In Paasi, A., Harrison, J., Jones, M. (eds.), Handbook on the Geographies of Regions and Territories (pp. 243-255). Cheltenham, UK \& Northampton, MA, USA: Edward Elgar.

KAUFMANN, E.P. \& ZIMMER, O. (1998). In Search of the authentic Nation: Landscape and National Identity in Canada and Switzerland. Nations and Nationalism, 4(4), 483-510. http://eprints.bbk.ac.uk/4214/1/4214.pdf.

KENNEDY, K.D. (2000). Visual Representation and National Identity in the Elementary Schoolbooks of Imperial Germany. Paedagogica Historica, 36(1), 224-245. DOI: 10.1080/0030923000360111

KIM, M. \& RYU, J.-M. (2014). Listening to Others' Voices (LOV) Project: An Empowering Strategy Incorporating Marginalized Perspectives. Journal of Geography, 113(6), 247-256.

KUČEROVÁ, S.R., KUČERA, Z., \& NOVOTNÁ, K. (2018). Formation of a regional image through geography textbooks: the case of north-west Bohemia. Norsk Geografisk Tidsskrift - Norwegian Journal of Geography, 72(3), 176195. DOI: $10.1080 / 00291951.2018 .1468811$.

LEFEBVRE, H. (1991). The Production of Space. Oxford, UK: Blackwell.

MÂRZA, R. (2015). “Primul război mondial reflectat în manualele școlare de istorie din România (până la 1989)” [World War I Reflected in History of Romania School Textbooks (until 1989)]. In Bolovan, I., Ghitta, O. (eds.), Istoria ca datorie. Omagiu academicianului loan-Aurel Pop la împlinirea vârstei de 60 de ani [History as Duty. Homage to the Academician loan-Aurel Pop for His 60th Birthday], (pp. 1035-1049). Cluj-Napoca: Academia Română. Centrul de Studii Transilvane.

MATTISSEK, A. (2010). Analyzing City Images. Potentials of the "French School of Discourse Analysis". Erdkunde, 64(4), 315-326. 
MATTISSEK, A. (2018). Geographic Methods: Discourse Analysis. In Oxford Bibliographies in Geography. New York: Oxford University Press, DOI: 10.1093/obo/9780199874002-0179

MATTISSEK, M. \& GLASZE, G. (2014). Discourse Analysis in German Language. Human Geography: Integrating Theory and Method. Social \& Cultural Geography, DOI: 10.1080/14649365.2014.961532

MITCHELL, W.J.T. (1994). Picture Theory: Essays on Verbal and Visual Representation. Chicago: University of Chicago Press.

MITCHELL, W.J.T. (1998). The Last Dinosaur Book: The Life and Times of a Cultural Icon. Chicago: University of Chicago Press.

MITCHELL, W.J.T. (2004). What do Pictures Want? The Lives and Loves of Images. Chicago: University of Chicago Press.

MURGOCI, G.M. \& POPA-BURCĂ, I. (1902). România şi ţěrile locuite de români: manual de geografie pentru uzul clasei IV secundare alcătuit conform programei analitice din 1899. Ediţia a 2-a. [Romania and the Lands Inhabited by Romanians: Geography School Textbook for the 4th Lower Secondary Grade, Written According to the Analytical Programme of 1899. 2nd Edition]. Bucureşti: Institutul de Arte Grafice „Carol Göbl”.

MURGOCI, G.M. \& POPA-BURCĂ, I. (1905). România şi ţările locuite de români: Manual de geografie pentru uzul clasei IV secundare. Ediţia a 3-a. [Romania and the Lands Inhabited by Romanians: Geography School Textbook for the 4th Lower Secondary Grade. 3rd Edition]. Bucureşti: Editura Societăţii Cooperative „Librăria Naţională”.

MURGOCI, G.M. \& POPA-BURCĂ, I. (1910). România şi ţările locuite de români: cu o introducere generală asupra Europei şi noţiuni de cosmografie: manual de Geografie pentru clasa IV secundară [Romania and the Lands Inhabited by Romanians: With a General Introduction on Europe and Cosmography Notions: Geography School Textbook for the 4th Lower Secondary Grade]. Bucureşti: Institutul de Arte Grafice "Carol Göbl”.

MURGOCI, G.M. \& POPA-BURCĂ, I. (1916). România şi ţările locuite de români, ediţia a VII-a [Romania and the Lands Inhabited by Romanians, 7th ed.]. Bucureşti: Institutul de Arte Grafice „Carol Göbl”.

NEWMAN, D. \& PAASI, A. (1998). Fences and Neighbours in the Postmodern World: Boundary Narratives in Political Geography. Progress in Human Geography, 22, 186-207.

NOGUE, J. \& VICENTE, J. (2004). Landscape and National Identity in Catalonia. Political Geography, 23, 113-132.

OKTAR, L. (2001). The Ideological Organisation of Representational Processes in the Presentation of Us and Them. Discourse and Society, 12(3), 313-346.

PAASI, A. \& METZGER, J. (2017). Foregrounding the Region. Regional Studies, 51(1), 19-30.

PAASI, A. (1986). The Institutionalization of Regions: A Theoretical Framework for Understanding the Emergence of Regions and the Constitution of Regional Identity. Fennia, 164(1), 105-146.

PAASI, A. (1991). Deconstructing Regions: Notes on the Scales of Spatial Life. Environment and Planning A, 23(2), 239-256.

PAASI, A. (1996). Territories, Boundaries and Consciousness. Chichester, Sussex: John Wiley.

PAASI, A. (1999). The Changing Pedagogies of Space: The Representation of the Other in Finnish School Geography Textbooks. In Brunn, S.D., Buttimer, A., Wardenga, U. (eds.), Text and Image: Social Construction of Regional Knowledges (pp. 226-237). Leipzig: Institut für Länderkunde.

PAASI, A. (2003). Region and Place: Regional Identity in Question. Progress in Human Geography, 27(4), 475-485.

PAASI, A. (2009). The Resurgence of the 'Region' and 'Regional Identity': Theoretical Perspectives and Empirical Observations on Regional Dynamics in Europe. Review of International Studies, 35, 121-146, doi:10.1017/S0260210509008456.

PAASI, A. (2010). Regions are Social Constructs, but Who or What Constructs Them? Agency in Question. Environment and Planning A, 42(10), 2296-2301.

PAASI, A. (2012). Border Studies Reanimated: Going beyond the Territorial/Relational Divide. Environment and Planning A, 44, 2303-2309. DOI:10.1068/a45282

PAASI, A. (2013). Regional Planning and the Mobilization of "Regional Identity": From Bounded Spaces to Relational Complexity. Regional Studies, 47(8), 1206-1219.

PAASI, A. (2019). From Bounded Spaces to Relational Social Constructs: Conceptualization of the Region in Geography, pp. 1-33, forthcoming. 
PAASI, A., HARRISON, J., \& JONES, M. (2018). New Consolidated Regional Geographies. In Paasi, A., Harrison, J., Jones, M. (eds.), Handbook on the Geographies of Regions and Territories (pp. 1-20). Cheltenham, UK and Northampton, MA, USA: Edward Elgar.

PAGLIARINI DE SOUZA, L.C., DRIGO, M.O., \& DA SILVA, P.C. (2015). The Otherness and the Brazilian Native People: A Study with Visual Representations in Textbooks. Conexao-Comunicacao e Cultura, 14(28), 51-71.

PONGAJARN, C., VAN DER DUIM, R., \& PETERS, K. (2014). Reading Postcards: Multiple Enactments of Tourism Destinations. The Case of Pai, Thailand. International Journal of Tourism Sciences, 14(1), 71-91. Retrieved 11 July 2019, from https://www.researchgate.net/publication/268744578_Reading_Postcards_Multiple_Enactments_of_Touri sm_Destinations

POTTER, J. (1996). Representing Reality. Discourse, Rhetoric and Social Construction. London: Sage Publications.

RICOEUR, P. (1991). Narrative Identity. Philosophy Today, 35(1), 73-81.

ROSE, G. (2014). Visual Methodologies. An Introduction to Researching with Visual Materials, 3rd ed. London: Sage.

RUMIANTSEV, S. (2010). Nationalism and the Construction of Maps of Historical Territories: Teaching National Histories in the Countries of the Southern Caucasus. Ab Imperio-Studies of New Imperial History and Nationalism in the Post-Soviet Space, 4, 415-461.

SABĂU, C.S. \& ILOVAN, O.-R. (2019). Versified Letters during World War I. Identity Affiliations and Coping Mechanisms in the Former Military Border District of Năsăud. Brvkenthal. Acta Mvsei, XIII. 5, Brukenthalia. Romanian Cultural History Review, 9, 839-852.

SABĂU, C.S. \& ONOFREIU, A. (2020). Editarea documentelor privind istoria locală între deziderat și realitate. Studiu de caz: granița năsăudeană, în volumul: Istoria și scrisul istoric azi. Opțiuni metodologice. Paradigme. Agendă. Lucrările Conferinței internaționale din 2-5 februarie 2020 dedicată Centenarului Institutului de Istorie "George Barițiu" din Cluj-Napoca, editori Susana Andea, losif Marin Balog, Ela Cosma, Attila Varga, Academia Română, Institutul de Istorie „George Barițiu”, Cluj-Napoca, Editura Școala Ardeleană (pp. 339-352).

SABĂU, C.S. (2015). „SSi ne-au făcut din grăniţeri, ţărani...”. Mentalităţi colective în satele năsăudene foste grănicereşti în a doua jumătate a secolului al XIX-lea ... ["And from military frontier guards they made us peasants ...". Collective Mentalities in the Former Military Frontier Villages, in Năsăud Region, during the Second Half of the 19th Century]. Cluj-Napoca: Editura Mega.

SILOVA, I., YAQUB, M.M., \& PALANDJIAN, G. (2014). Pedagogies of Space. (Re)Mapping National Territories, Borders, and Identities in Post-Soviet Textbooks. In Williams, J.H. (ed.), (Re)Constructing Memory: School Textbooks and the Imagination (pp. 103-128). Rotterdam: SENSE Publishers. DOI 10.1007/978-94-6209-656-1.

SÖDERSTRÖM, O. (2010). Representation. In Sibley, D., Atkinson, D., Jackson, P. (eds.), Cultural Geography: A Critical Dictionary of Key Ideas (pp. 11-15). London, New York: I.B.Tauris.

TERLOUW, K. \& VAN GORP, B. (2014). Layering Spatial Identities: The Identity Discourses of New Regions'. Environment and Planning A, 46(4), 852-866.

TERLOUW, K. (2017). Local Identities and Politics: Negotiating the Old and the New. London: Routledge.

VERDERY, K. (1991). National Ideology under Socialism: Identity and Cultural Politics in Ceauşescu's Romania. Berkeley: University of California Press. http://dx.doi.org/10.1525/california/9780520072169.001.0001

WEINGART, P. \& STEHR, N. (eds.) (2000). Practising Interdisciplinarity. Toronto: University of Toronto Press.

WEINGART, P. (2000). Interdisciplinarity. The Paradoxical Discourse. In Weingart, P., Stehr, N. (eds.), Practising Interdisciplinarity (pp. 25-42). Toronto: University of Toronto Press.

WILSON, T.M. \& DONNAN, H. (2012). Borders and Border Studies. In Wilson, T. M., Donnan, H. (eds.), A Companion to Border Studies (pp. 1-25). Oxford: Blackwell.

WODAK, R., DE CILLIA, R., REISIGL, M., \& LIEBHART, K. (1999). The Discoursive Construction of National Identity. Edingburgh: Edingburgh University Press. 